\title{
LEVEL II SCOUR ANALYSIS FOR BRIDGE 29 (JAMATH00300029) on TOWN HIGHWAY 30, crossing BALL MOUNTAIN BROOK, JAMAICA, VERMONT
}

Open-File Report 98-88

Prepared in cooperation with

VERMONT AGENCY OF TRANSPORTATION and

FEDERAL HIGHWAY ADMINISTRATION

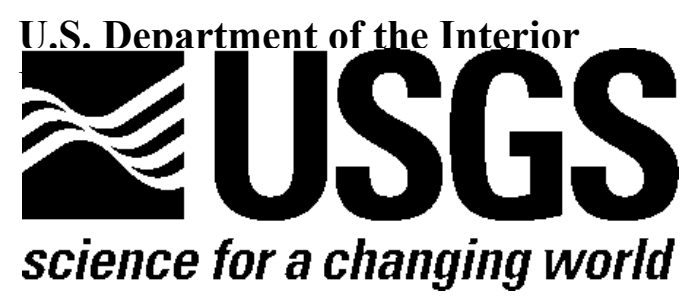




\section{LEVEL II SCOUR ANALYSIS FOR BRIDGE 29 (JAMATH00300029) on TOWN HIGHWAY 30, crossing BALL MOUNTAIN BROOK, JAMAICA, VERMONT \\ By JAMES R. DEGNAN}

U.S. Geological Survey Open-File Report 98-88

Prepared in cooperation with

VERMONT AGENCY OF TRANSPORTATION and

FEDERAL HIGHWAY ADMINISTRATION 


\title{
U.S. DEPARTMENT OF THE INTERIOR BRUCE BABBITT, Secretary
}

\author{
U.S. GEOLOGICAL SURVEY
}

Thomas J. Casadevall, Acting Director

For additional information write to:

District Chief

U.S. Geological Survey 361 Commerce Way

Pembroke, NH 03275-3718
Copies of this report may be purchased from:

U.S. Geological Survey

Branch of Information Services

Open-File Reports Unit

Box 25286

Denver, CO 80225-0286 


\section{CONTENTS}

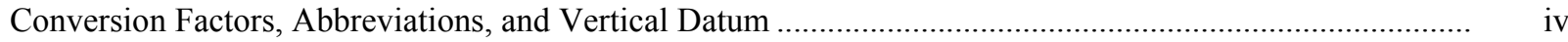

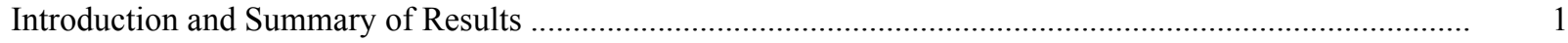

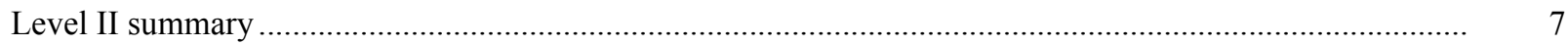

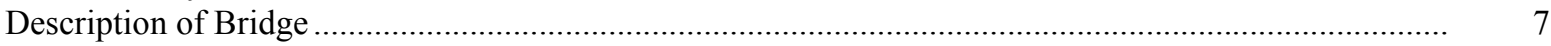

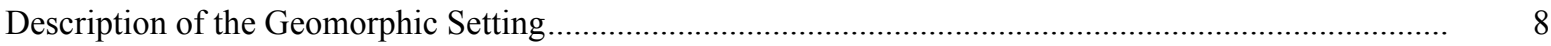

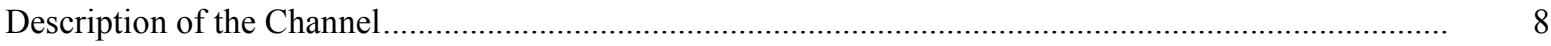

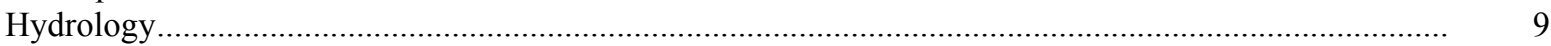

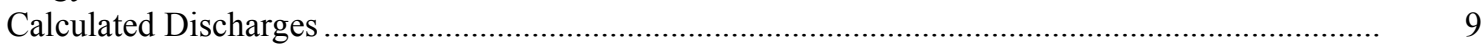

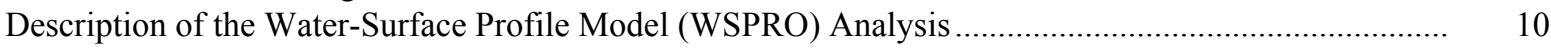

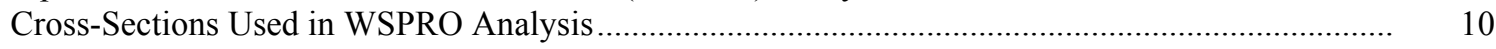

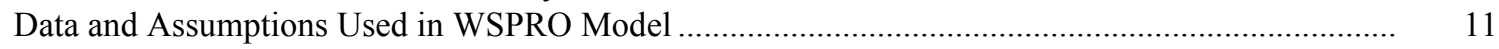

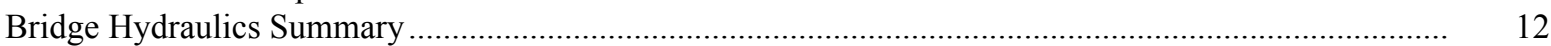

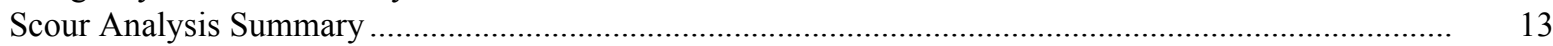

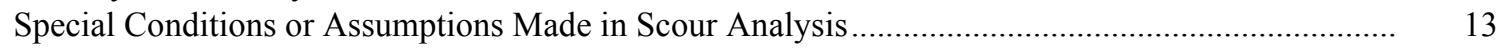

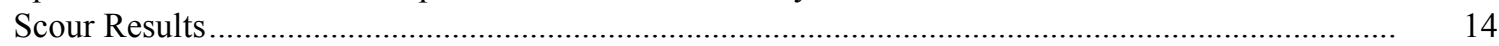

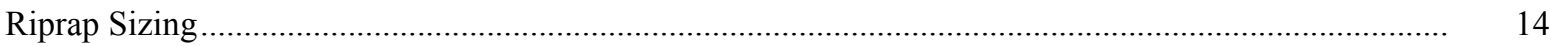

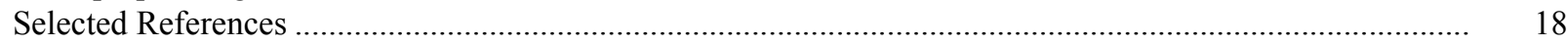

Appendices:

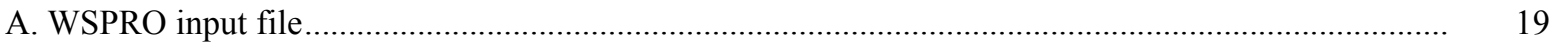

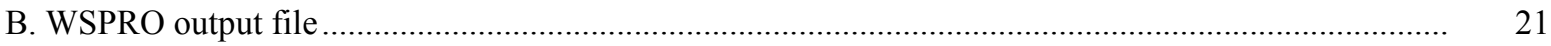

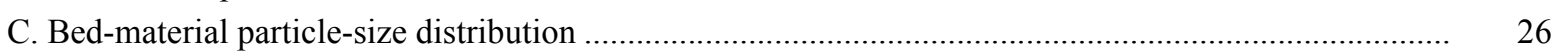

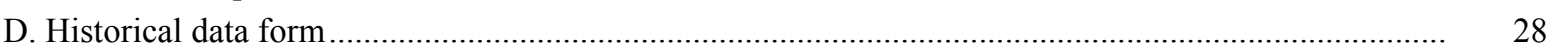

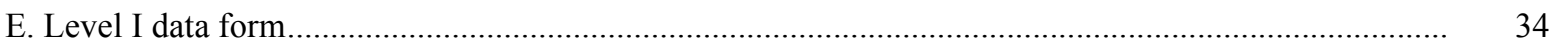

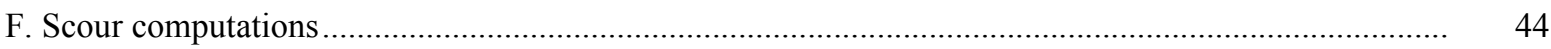

\section{FIGURES}

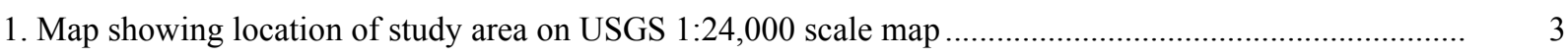

2. Map showing location of study area on Vermont Agency of Transportation town

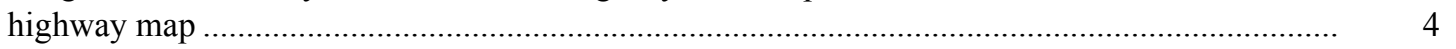

3. Structure JAMATH00300029 viewed from upstream (August 12, 1996)........................................... 5

4. Downstream channel viewed from structure JAMATH00300029 (August 12, 1996)............................ 5

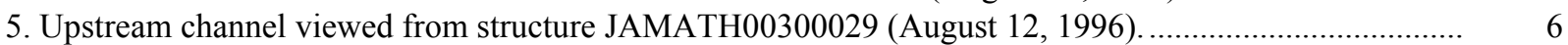

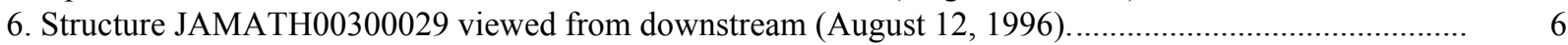

7. Water-surface profiles for the 100- and 500-year discharges at structure JAMATH00300029 on Town Highway 30, crossing Ball Mountain Brook,

Jamaica, Vermont.

8. Scour elevations for the 100- and 500-year discharges at structure JAMATH00300029 on Town Highway 30, crossing Ball Mountain Brook, Jamaica, Vermont.

\section{TABLES}

1. Remaining footing/pile depth at abutments for the 100-year discharge at structure JAMATH00300029 on Town Highway 30, crossing Ball Mountain Brook, Jamaica, Vermont

2. Remaining footing/pile depth at abutments for the 500-year discharge at structure JAMATH00300029 on Town Highway 30, crossing Ball Mountain Brook, Jamaica, Vermont.. 


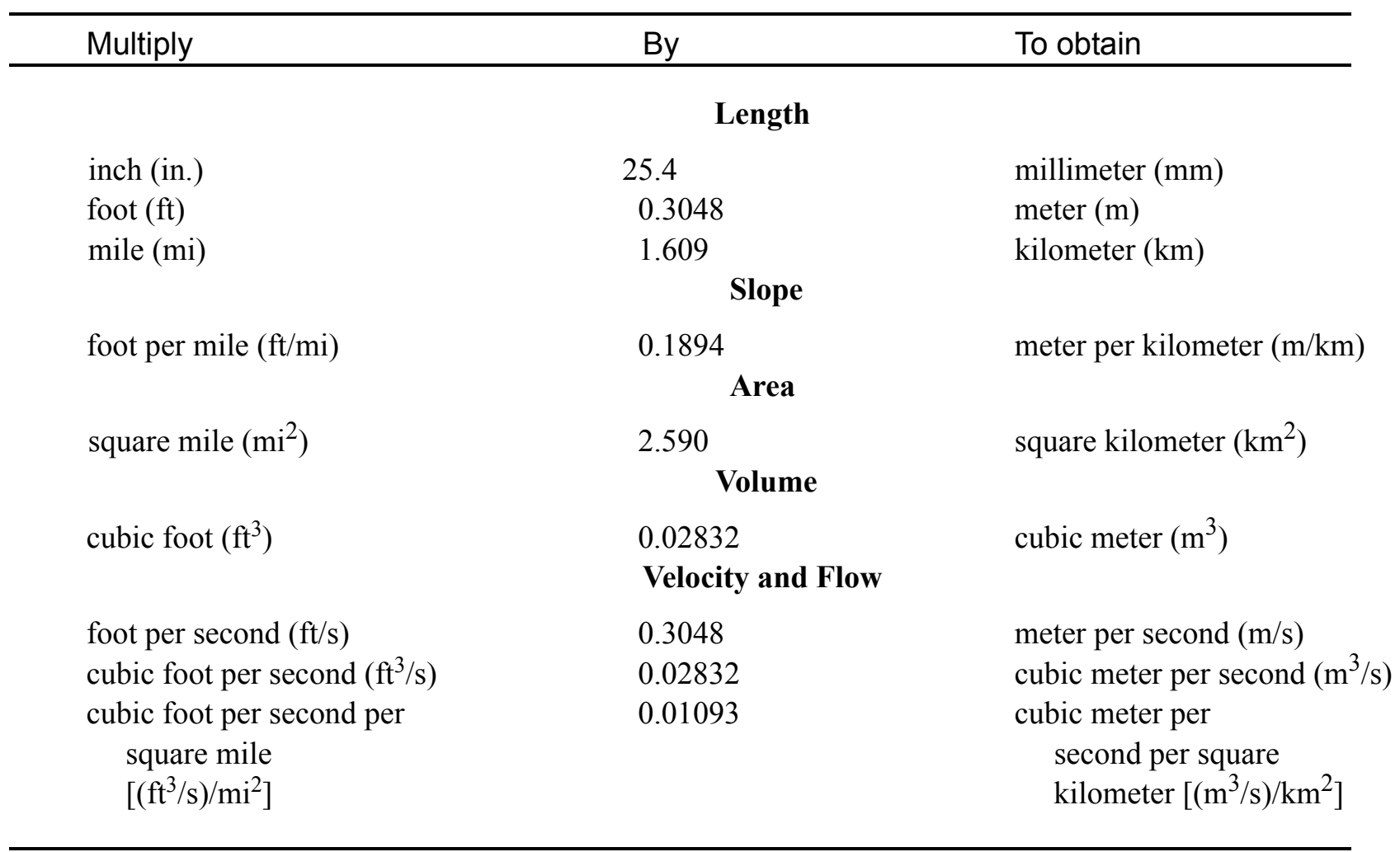

\section{OTHER ABBREVIATIONS}

$\begin{array}{lrlr}\text { BF } & \begin{array}{r}\text { bank full } \\ \text { cfs }\end{array} & \text { LWW } & \text { left wingwall } \\ \mathrm{D}_{50} & \text { median feet per second } & \text { Max } & \text { maximum } \\ \mathrm{DS} & \text { main channel } \\ \mathrm{elev} & \text { downstream } & \text { RAB } & \text { elevation } \\ \mathrm{f} / \mathrm{p} & \text { RABUT } & \text { right abutment } \\ \mathrm{ft} & \text { flood plain } & \text { RB } & \text { face of right abutment } \\ \mathrm{ft} / \mathrm{ft} & \text { square feet } & \text { ROB } & \text { right bank } \\ \text { FEMA } & \text { feet per foot } & \text { RWW } & \text { right overbank } \\ \text { FHWA } & \text { Federal Emergency Management Agency } & \text { TH } & \text { right wingwall } \\ \text { JCT } & \text { Federal Highway Administration } & \text { UB } & \text { town highway } \\ \text { LAB } & \text { junction } & \text { US } & \text { under bridge } \\ \text { LABUT } & \text { left abutment } & \text { USGS } & \text { upstream } \\ \text { LB } & \text { face of left abutment } & \text { VTAOT } & \text { Vermont Agency of Transportation } \\ \text { LOB } & \text { left bank } & \text { WSPRO } & \text { water-surface profile model } \\ & \text { left overbank } & \text { yr } & \text { year }\end{array}$

In this report, the words "right" and "left" refer to directions that would be reported by an observer facing downstream. Sea level: In this report, "sea level" refers to the National Geodetic Vertical Datum of 1930-- a geodetic datum derived from a general adjustment of the first-order level nets of the United States and Canada, formerly called Sea Level Datum of 1930 .

In the appendices, the above abbreviations may be combined. For example, USLB would represent upstream left bank. 


\title{
LEVEL II SCOUR ANALYSIS FOR BRIDGE 29 (JAMATH00300029) ON TOWN HIGHWAY 30, CROSSING BALL MOUNTAIN BROOK, JAMAICA, VERMONT
}

\author{
By James R. Degnan
}

\section{INTRODUCTION AND SUMMARY OF RESULTS}

This report provides the results of a detailed Level II analysis of scour potential at structure JAMATH00300029 on Town Highway 30 crossing Ball Mountain Brook, Jamaica, Vermont (figures 1-8). A Level II study is a basic engineering analysis of the site, including a quantitative analysis of stream stability and scour (Federal Highway Administration, 1993). Results of a Level I scour investigation also are included in appendix $E$ of this report. A Level I investigation provides a qualitative geomorphic characterization of the study site. Information on the bridge, gleaned from Vermont Agency of Transportation (VTAOT) files, was compiled prior to conducting Level I and Level II analyses and is found in appendix D.

The site is in the Green Mountain section of the New England physiographic province in southern Vermont. The 10.4- $\mathrm{mi}^{2}$ drainage area is in a predominantly rural and forested basin. In the vicinity of the study site, the surface cover is forest with some lawn on the upstream and downstream left bank.

In the study area, Ball Mountain Brook has an incised, sinuous channel with a slope of approximately $0.02 \mathrm{ft} / \mathrm{ft}$, an average channel top width of $76 \mathrm{ft}$ and an average bank height of $4 \mathrm{ft}$. The channel bed material ranges from gravel to boulders with a median grain size $\left(\mathrm{D}_{50}\right)$ of $122.0 \mathrm{~mm}(0.400 \mathrm{ft})$. The geomorphic assessment at the time of the Level I and Level II site visit on August 12, 1996, indicated that the reach was laterally unstable. There are cut-banks on the upstream and downstream banks.

The Town Highway 30 crossing of Ball Mountain Brook is a 84-ft-long, one-lane bridge consisting of one 80-foot steel-beam span (Vermont Agency of Transportation, written communication, March 30,1995). The opening length of the structure parallel to the bridge face is $77.4 \mathrm{ft}$. The bridge is supported by vertical, laid-up stone abutments. The channel is not skewed to the opening and does not have an opening-skew-to-roadway. 
A scour hole $2.5 \mathrm{ft}$ deeper than the mean thalweg depth was observed in the upstream channel during the Level I assessment. The only scour protection measure at the site was type-2 stone fill (less than 36 inches diameter) along the upstream and downstream left banks, the left and right abutments, and the downstream right bank. Additional details describing conditions at the site are included in the Level II Summary and appendices D and E.

Scour depths and recommended rock rip-rap sizes were computed using the general guidelines described in Hydraulic Engineering Circular 18 (Richardson and Davis, 1995). Total scour at a highway crossing is comprised of three components: 1) long-term streambed degradation; 2) contraction scour (due to accelerated flow caused by a reduction in flow area at a bridge) and; 3) local scour (caused by accelerated flow around piers and abutments). Total scour is the sum of the three components. Equations are available to compute depths for contraction and local scour and a summary of the results of these computations follows.

Contraction scour for all modelled flows ranged from $0.1 \mathrm{ft}$ to $0.5 \mathrm{ft}$. The worst-case contraction scour occurred at the 500-year discharge. Abutment scour ranged from 8.1 to $11.0 \mathrm{ft}$. The worst-case abutment scour occurred at the 500-year discharge. Additional information on scour depths and depths to armoring are included in the section titled "Scour Results". Scoured-streambed elevations, based on the calculated scour depths, are presented in tables 1 and 2. A cross-section of the scour computed at the bridge is presented in figure 8. Scour depths were calculated assuming an infinite depth of erosive material and a homogeneous particle-size distribution.

It is generally accepted that the Froehlich equation (abutment scour) gives "excessively conservative estimates of scour depths" (Richardson and Davis, 1995, p. 47). Usually, computed scour depths are evaluated in combination with other information including (but not limited to) historical performance during flood events, the geomorphic stability assessment, existing scour protection measures, and the results of the hydraulic analyses. Therefore, scour depths adopted by VTAOT may differ from the computed values documented herein. 


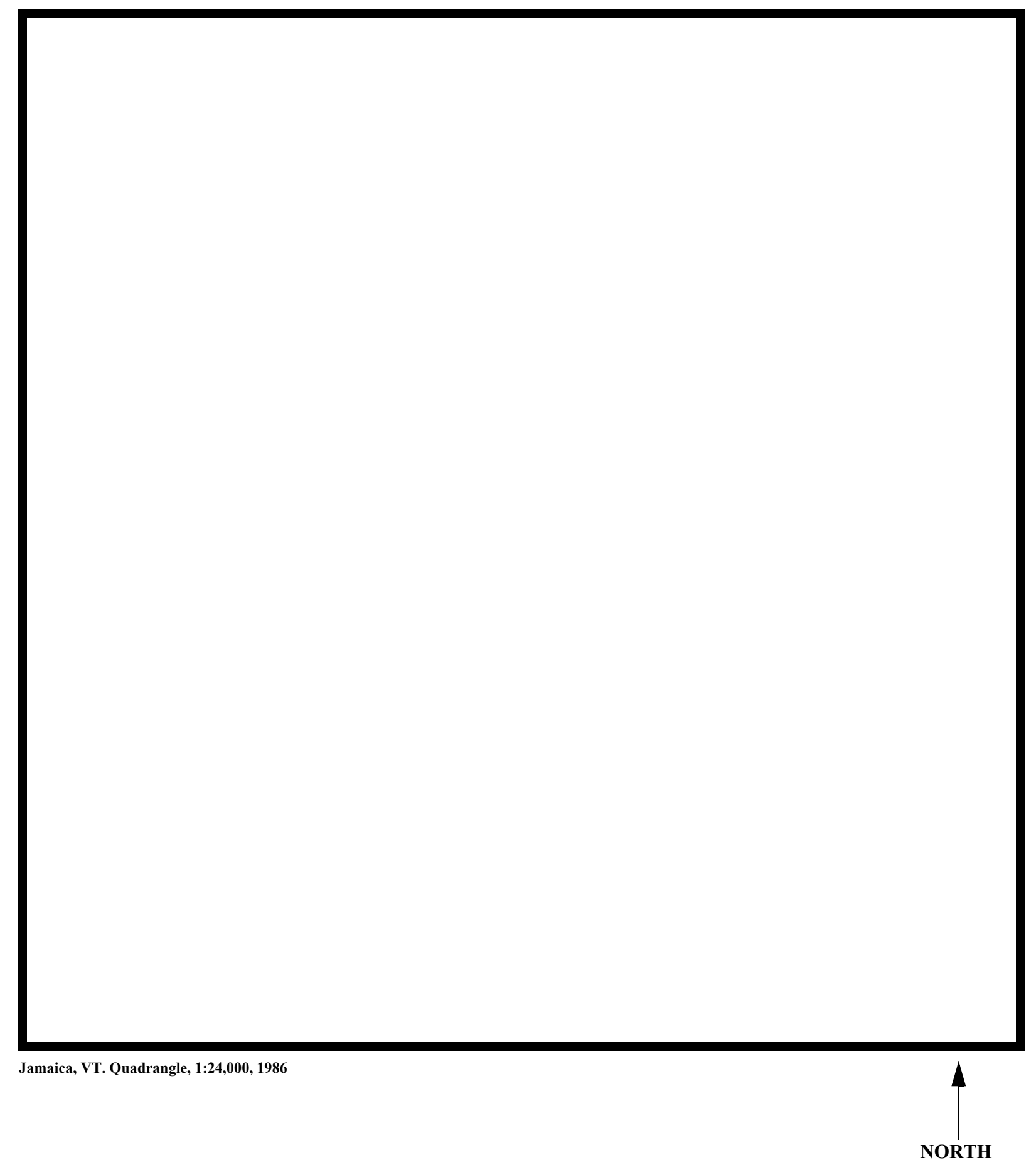

Figure 1. Location of study area on USGS 1:24,000 scale map. 
Figure 2. Location of study area on Vermont Agency of Transportation town highway map. 

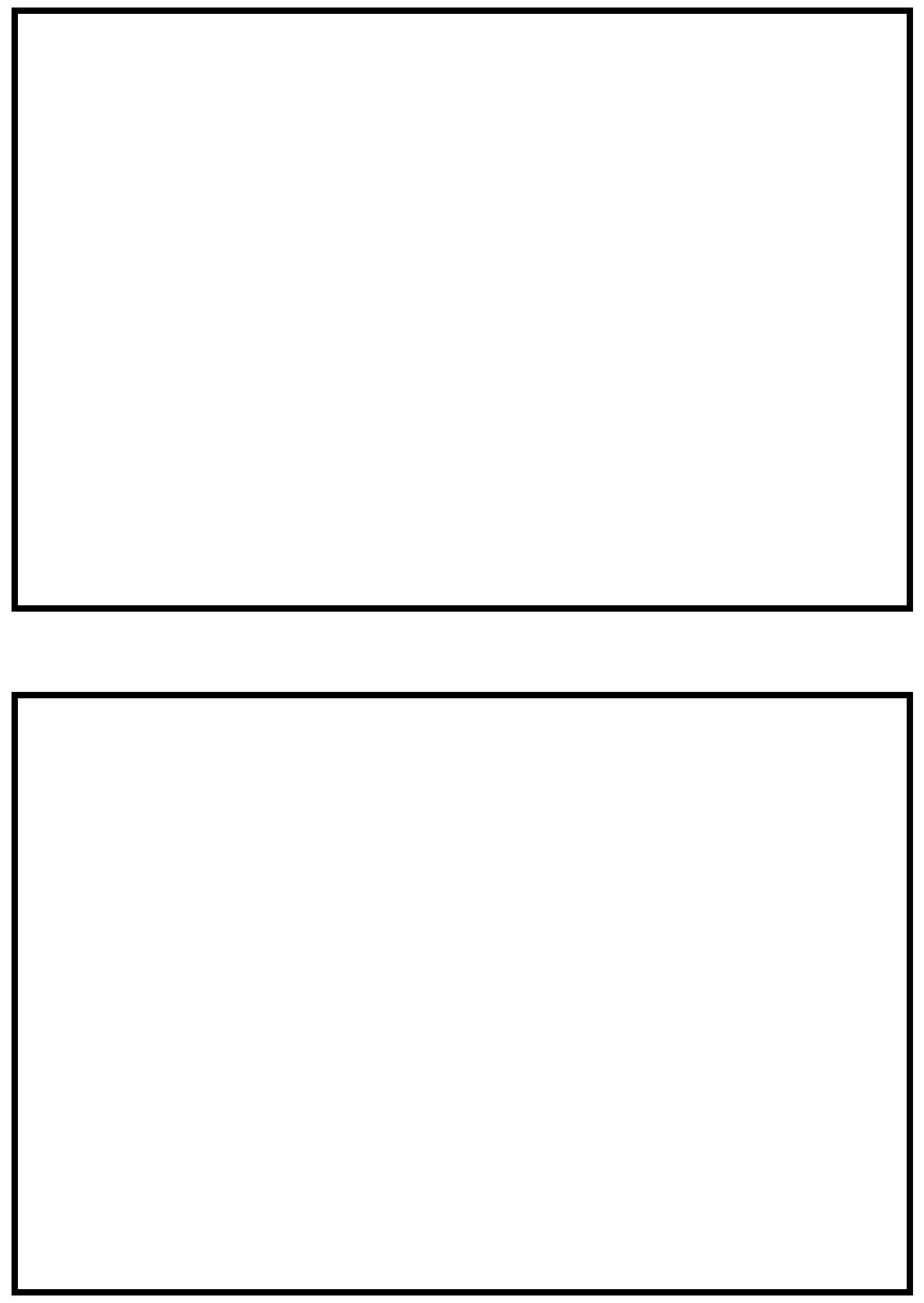

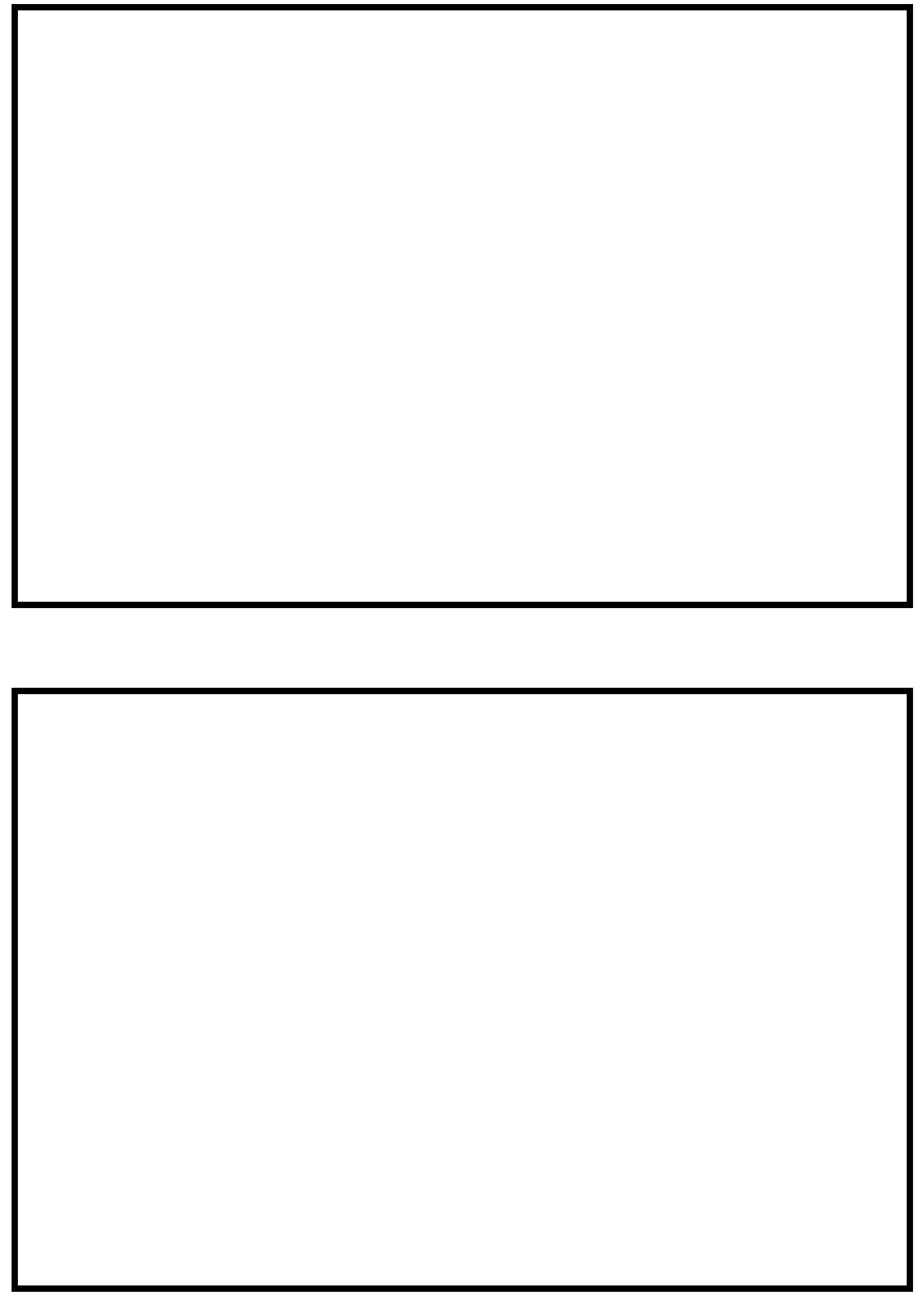


\section{LEVEL II SUMMARY}

\begin{tabular}{llllll} 
Structure Number & JAMATH00300029 & & \multicolumn{3}{c}{ Ball Mountain Brook } \\
Stream & & & \\
County & Windham & Road & TH30 & District & 2
\end{tabular}

\section{Description of Bridge}

Bridge length $\frac{84}{} \boldsymbol{f t} \quad$ Bridge width $\frac{14}{f t} \quad$ Max span length $\frac{80}{f t}$ Alignment of bridge to road (on curve or straight) Spill-through Abutment type

Stone fill on abutment?

$$
\text { Yes }
$$

\section{Embankment type} Straight

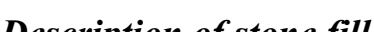
Mrto nf insnortinn
Type-2, along the upstream and downstream left banks, the left and Sloping right abutments, and the downstream right bank.

Abutments are laid-up stone walls with stone fill spillthrough embankments in front of each abutment.

\section{No}

Is bridge skewed to flood flow according to No ' survey?

Angle

Debris accumulation on bridge at time of Level I or Level II site visit:

\begin{tabular}{|c|c|c|c|}
\hline & $\begin{array}{c}\text { Date of insnortion } \\
8 / 12 / 96\end{array}$ & $\begin{array}{l}\text { Percent of almmant } \\
\text { blocked inortzontatly }\end{array}$ & $\begin{array}{l}\text { Percent of } 0 \\
\text { blocked verticatty }\end{array}$ \\
\hline Level I & $8 / 12 / 96$ & 0 & 0 \\
\hline $\begin{array}{l}\text { Level II } \\
\text { the bridge. }\end{array}$ & \multicolumn{3}{|c|}{ High. There was debris accumulation observed both upstream and at } \\
\hline
\end{tabular}

There is a cobble, gravel, and boulder point bar along the right abutment that affects low flow as Doscriho any foaturos noar ar at tho hridoo that mav' affort flow, (includo ahsorvation dato) of $8 / 12 / 96$. 


\section{Description of the Geomorphic Setting}

General topography The channel is located within a moderate relief valley with a steep valley wall on the right side.

Geomorphic conditions at bridge site: downstream (DS), upstream (US)

Date of inspection $\quad 8 / 12 / 96$

DS left: $\quad$ Steep channel bank to a moderately sloped overbank

DS right: $\quad$ Steep channel bank and valley wall

US left: $\quad$ Steep channel bank to a moderately sloped overbank

US right: Steep channel bank and valley wall

\section{Description of the Channel}

\begin{tabular}{|c|c|c|c|}
\hline & & & 4 \\
\hline Average top width & $\stackrel{\boldsymbol{f t}}{\text { Boulders/Cobbles }}$ & Average depth & Cobbles/Boulders \\
\hline
\end{tabular}

Predominant bed material Bank material

Sinuous with non-

alluvial channel boundaries and irregular point and lateral bars.

$8 / 12 / 96$

Vegetative co 1 Trees

DS left: $\quad$ Trees

DS right: Trees

US left: $\quad$ Sparse trees and grass

US right: $\quad$ No

Do banks appear stable? There has been a land slide on the upstream right bank, in the same area as the cut-bank. There are two cut-banks on the downstream left bank.

None as of $8 / 12 / 96$.

Describe any obstructions in channel and date of observation. 


\title{
Hydrology
}

Drainage area $\frac{10.4}{m^{2}}{ }^{2}$

Percentage of drainage area in physiographic provinces: (approximate)

Physiographic province/section

New England/Green Mountain
Percent of drainage area 100

\begin{abstract}
Is drainage area considered rural or urban?
Rural urbanization:

Describe any significant
\end{abstract}

Is there a USGS gage on the stream of interest? $\frac{\mathrm{No}}{--}$
USGS gage description

USGS gage number

Gage drainage area $\mathrm{mi}^{2}$

No

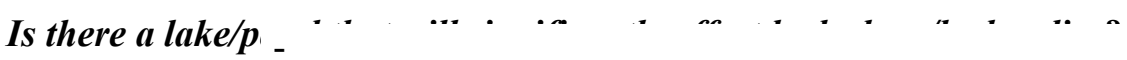

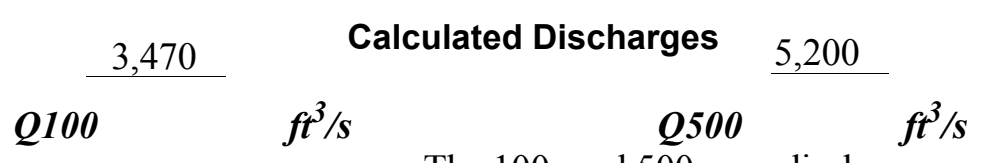

The 100- and 500-year discharges are based on a

drainage area relationship [(10.4/10.1)exp 0.67] with flood frequency estimates available from the VTAOT database (written communication, May 1995) for bridge number 21 in Jamaica. Bridge number 21 crosses Ball Mountain Brook upstream of this site and a drainage area of 10.1 square miles. These area adjusted discharges are within a range defined by empirical flood frequency relationships (Benson, 1962; Johnson and Tasker, 1974; FHWA, 1983; Potter, 1957a\&b; Talbot, 1887). Each curve was extended graphically to the 500-year event. 


\section{Description of the Water-Surface Profile Model (WSPRO) Analysis}

Datum for WSPRO analysis (USGS survey, sea level, VTAOT plans)

USGS survey

Datum tie between USGS survey and VTAOT plans

None

Description of reference marks used to determine USGS datum. $\quad$ RM1 is a chiseled X on top of the upstream end of the right abutment (elev. $501.13 \mathrm{ft}$, arbitrary survey datum). RM2 is a nail in a telephone pole $50 \mathrm{ft}$. from the bridge along the upstream side of the left road approach (elev. $506.37 \mathrm{ft}$, arbitrary survey datum).

\section{Cross-Sections Used in WSPRO Analysis}

\begin{tabular}{cccl}
\hline${ }^{1}$ Cross-section & $\begin{array}{c}\text { Section } \\
\text { Reference } \\
\text { Distance } \\
\text { (SRD) in feet }\end{array}$ & $\begin{array}{c}{ }^{2} \text { Cross-section } \\
\text { development }\end{array}$ & \multicolumn{1}{c}{ Comments } \\
\hline EXITX & -69 & 1 & $\begin{array}{l}\text { Exit section } \\
\text { Full-valley section (Tem- } \\
\text { plated from EXITX and } \\
\text { FULLV }\end{array}$ \\
BRIDG & 0 & 3 & $\begin{array}{l}\text { Bodified) } \\
\text { Bridge section }\end{array}$ \\
RDWAY & 0 & 1 & Road Grade section \\
APPRO & 8 & 1 & Approach section \\
\hline
\end{tabular}

${ }^{1}$ For location of cross-sections see plan-view sketch included with Level I field form, Appendix E. For more detail on how cross-sections were developed see WSPRO input file. 


\section{Data and Assumptions Used in WSPRO Model}

Hydraulic analyses of the reach were done by use of the Federal Highway Administration's WSPRO step-backwater computer program (Shearman and others, 1986, and Shearman, 1990). The analyses reported herein reflect conditions existing at the site at the time of the study. Furthermore, in the development of the model it was necessary to assume no accumulation of debris or ice at the site. Results of the hydraulic model are presented in the Bridge Hydraulic Summary, appendix B, and figure 7.

Channel roughness factors (Manning's " $n$ ") used in the hydraulic model were estimated using field inspections at each cross section following the general guidelines described by Arcement and Schneider (1989). Final adjustments to the values were made during the modelling of the reach. Channel " $\mathrm{n}$ " values for the reach ranged from 0.070 to 0.075 , and the overbank "n" value was 0.075 .

Normal depth at the exit section (EXITX) was assumed as the starting water surface. This depth was computed by use of the slope-conveyance method outlined in the user's manual for WSPRO (Shearman, 1990). The slope used was $0.0236 \mathrm{ft} / \mathrm{ft}$, which was the slope of the 100year water surface profile downstream of the site according to the Flood Insurance Study for the town of Jamaica, Vermont (Federal Emergency Management Agency, May 17, 1988).

The surveyed approach section (APPRO) was one bridge length upstream of the upstream face as recommended by Shearman and others (1986). This location provides a consistent method for determining scour variables.

For the 100-year and 500-year discharge, WSPRO assumes critical depth at the bridge section. Supercritical models were developed for these discharges. After analyzing both the supercritical and subcritical profiles for each discharge, it was determined that the water surface profile does pass through critical depth within the bridge opening. Thus, the assumptions of critical depth at the bridge are satisfactory solutions. 


\section{Bridge Hydraulics Summary}

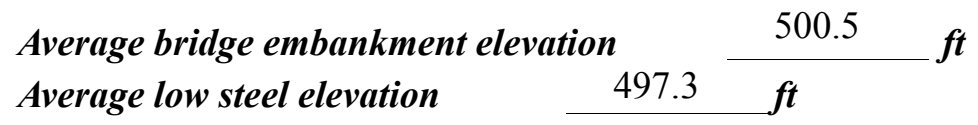

$$
\text { 100-year discharge } \quad 3,470 \quad \mathrm{ft}^{3} / \mathrm{s}
$$

Water-surface elevation in bridge opening $\quad 488.9 \quad \boldsymbol{f t}$

Road overtopping? ___ No Discharge over road ___-- $\mathrm{ft}^{3} / \mathrm{s}$

Area of flow in bridge opening $\quad 282 \quad \mathrm{ft}^{2}$

Average velocity in bridge opening $12.3 \mathrm{ft} / \mathrm{s}$

Maximum WSPRO tube velocity at bridge $15.6 \mathrm{ft} / \mathrm{s}$

Water-surface elevation at Approach section with bridge 493.9

Water-surface elevation at Approach section without bridge $\quad 491.8$

Amount of backwater caused by bridge $\quad 2.1$ it

500-year discharge $\quad 5,200 \quad \mathrm{ft}^{3} / \mathrm{s}$

Water-surface elevation in bridge opening $490.6 \mathrm{ft}$

Road overtopping? ____ No Discharge over road ___ -- $\mathrm{ft}^{3} / \mathrm{s}$

Area of flow in bridge opening $\quad 383 \quad \mathrm{ft}^{2}$

Average velocity in bridge opening $13.6 \mathrm{ft} / \mathrm{s}$

Maximum WSPRO tube velocity at bridge 17.4 's

Water-surface elevation at Approach section with bridge 495.8

Water-surface elevation at Approach section without bridge $\quad 493.1$

Amount of backwater caused by bridge $\quad 2.7, t$

Incipient overtopping discharge ___ -- $\mathrm{ft}^{3} / \mathrm{s}$

Water-surface elevation in bridge opening $\quad--\quad t$

Area of flow in bridge opening _ _- $\mathrm{ft}^{2}$

Average velocity in bridge opening ___ $\quad--\quad f t / s$

Maximum WSPRO tube velocity at bridge _ -- $\mathrm{ft} / \mathrm{s}$

Water-surface elevation at Approach section with bridge

Water-surface elevation at Approach section without bridge

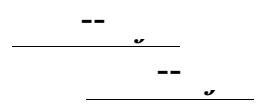
Amount of backwater caused by bridge _ 


\section{Scour Analysis Summary}

\section{Special Conditions or Assumptions Made in Scour Analysis}

Scour depths were computed using the general guidelines described in Hydraulic Engineering Circular 18 (Richardson and Davis, 1995). Scour depths were calculated assuming an infinite depth of erosive material and a homogeneous particle-size distribution. The results of the scour analysis for the 100-year and 500-year discharges are presented in tables 1 and 2 and a graph of the scour depths is presented in figure 8 .

Contraction scour for the 100-year and 500-year discharges was computed by use of the Laursen clear-water contraction scour equation (Richardson and Davis, 1995, p. 32, equation 20). The streambed armoring depths computed suggest that armoring will not limit the depth of contraction scour.

Abutment scour was computed by use of the Froehlich equation (Richardson and Davis, 1995, p. 48, equation 28). Variables for the Froehlich equation include the Froude number of the flow approaching the embankments, the length of the embankment blocking flow, and the depth of flow approaching the embankment less any roadway overtopping.

Because the influence of scour processes on the spill-through embankment material is uncertain, the scour depth at the vertical laid-up stone abutment walls is unknown. Therefore, the total scour depth computed at the toe of the embankment was applied for the entire spill-through embankment, as shown in figure 8 . 


\section{Scour Results}

100-yr discharge 500-yr discharge

Incipient

Contraction scour:

(Scour depths in feet)

Main channel

Live-bed scour

Clear-water scour

Depth to armoring

Left overbank

Right overbank

Local scour:

Abutment scour

Left abutment

8.1

10.6

9.9-

11.0

\section{Right abutment}

Pier scour

Pier 1

Pier 2

Pier 3

Abutments:

Left abutment

Right abutment

Piers:

Pier 1

Pier 2

overtopping discharge 


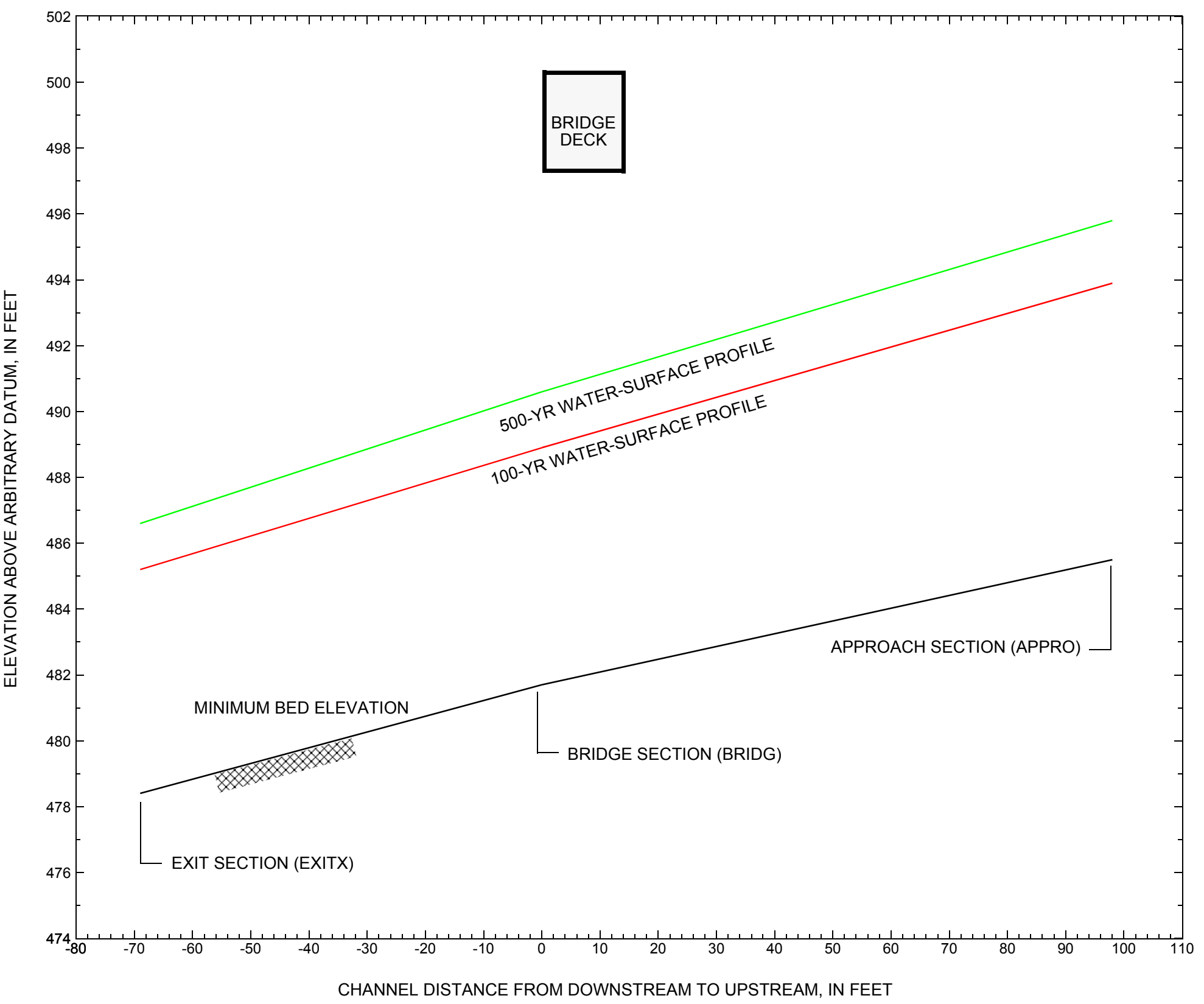

Figure 7. Water-surface profiles for the 100- and 500-yr discharges at structure JAMATH00300029 on Town Highway 30, crossing Ball Mountain Brook, Jamaica, Vermont. 


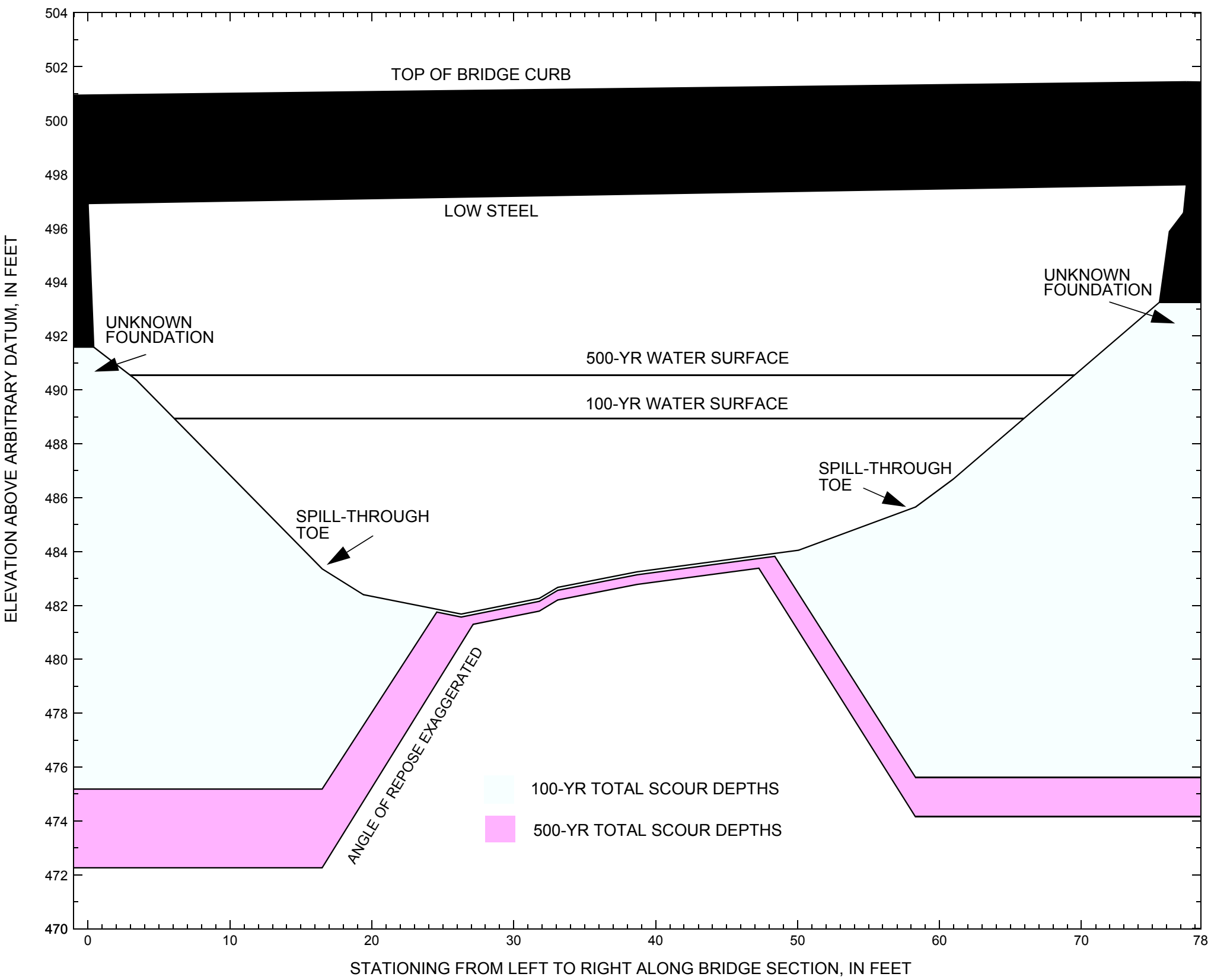

Figure 8. Scour elevations for the 100- and 500-yr discharges at structure JAMATH00300029 on Town Highway 30, crossing Ball Mountain Brook, Jamaica, Vermont. 
Table 1. Remaining footing/pile depth at abutments for the 100-yr discharge at structure JAMATH00300029 on Town Highway 30, crossing Ball Mountain Brook, Jamaica, Vermont.

[VTAOT, Vermont Agency of Transportation; --,no data]

\begin{tabular}{|c|c|c|c|c|c|c|c|c|c|c|c|}
\hline Description & Station $^{1}$ & $\begin{array}{c}\text { VTAOT } \\
\text { average } \\
\text { bridge seat } \\
\text { elevation } \\
\text { (feet) }\end{array}$ & $\begin{array}{l}\text { Surveyed } \\
\text { minimum } \\
\text { low-chord } \\
\text { elevation }{ }^{2} \\
\text { (feet) }\end{array}$ & $\begin{array}{c}\text { Bottom of } \\
\text { footing/pile } \\
\text { elevation }{ }^{2} \\
\text { (feet) }\end{array}$ & $\begin{array}{c}\text { Channel } \\
\text { elevation at } \\
\text { abutment/ } \\
\text { pier }^{2} \\
\text { (feet) }\end{array}$ & $\begin{array}{l}\text { Contraction } \\
\text { scour depth } \\
\text { (feet) }\end{array}$ & $\begin{array}{l}\text { Abutment } \\
\text { scour } \\
\text { depth } \\
\text { (feet) }\end{array}$ & $\begin{array}{l}\text { Pier } \\
\text { scour } \\
\text { depth } \\
\text { (feet) }\end{array}$ & $\begin{array}{l}\text { Depth of } \\
\text { total scour } \\
\text { (feet) }\end{array}$ & $\begin{array}{c}\text { Elevation of } \\
\text { scour }^{2} \\
\text { (feet) }\end{array}$ & $\begin{array}{c}\text { Remaining } \\
\text { footing/pile } \\
\text { depth } \\
\text { (feet) }\end{array}$ \\
\hline \multicolumn{12}{|c|}{100 -yr discharge is 3,470 cubic-feet per second } \\
\hline Left abutment & 0.0 & -- & 496.9 & -- & 491.6 & -- & -- & -- & -- & -- & -- \\
\hline LABUT toe & 16.5 & -- & -- & -- & 483.4 & 0.1 & 8.1 & -- & 8.2 & 475.2 & -- \\
\hline RABUT toe & 58.3 & -- & -- & -- & 485.7 & 0.1 & 9.9 & -- & 10.0 & 475.7 & -- \\
\hline Right abutment & 77.4 & -- & 497.6 & -- & 493.3 & -- & -- & -- & -- & -- & -- \\
\hline
\end{tabular}

1.Measured along the face of the most constricting side of the bridge.

2.Arbitrary datum for this study.

Table 2. Remaining footing/pile depth at abutments for the 500-yr discharge at structure JAMATH00300029 on Town Highway 30 crossing Ball Mountain Brook, Jamaica, Vermont.

[VTAOT, Vermont Agency of Transportation; --, no data]

\begin{tabular}{|c|c|c|c|c|c|c|c|c|c|c|c|}
\hline Description & Station $^{1}$ & $\begin{array}{l}\text { VTAOT } \\
\text { average } \\
\text { bridge seat } \\
\text { elevation } \\
\text { (feet) }\end{array}$ & $\begin{array}{l}\text { Surveyed } \\
\text { minimum } \\
\text { low-chord } \\
\text { elevation }{ }^{2} \\
\text { (feet) }\end{array}$ & $\begin{array}{c}\text { Bottom of } \\
\text { footing/pile } \\
\text { elevation }{ }^{2} \\
\text { (feet) }\end{array}$ & $\begin{array}{c}\text { Channel } \\
\text { elevation at } \\
\text { abutment/ } \\
\text { pier }^{2} \\
\text { (feet) }\end{array}$ & $\begin{array}{l}\text { Contraction } \\
\text { scour depth } \\
\text { (feet) }\end{array}$ & $\begin{array}{l}\text { Abutment } \\
\text { scour } \\
\text { depth } \\
\text { (feet) }\end{array}$ & $\begin{array}{l}\text { Pier } \\
\text { scour } \\
\text { depth } \\
\text { (feet) }\end{array}$ & $\begin{array}{l}\text { Depth of } \\
\text { total scour } \\
\text { (feet) }\end{array}$ & $\begin{array}{c}\text { Elevation of } \\
\text { scour }^{2} \\
\text { (feet) }\end{array}$ & $\begin{array}{c}\text { Remaining } \\
\text { footing/pile } \\
\text { depth } \\
\text { (feet) }\end{array}$ \\
\hline \multicolumn{12}{|c|}{500 -yr discharge is 5,200 cubic-feet per second } \\
\hline Left abutment & 0.0 & -- & 496.9 & -- & 491.6 & -- & -- & -- & -- & -- & -- \\
\hline LABUT toe & 16.5 & -- & -- & -- & 483.4 & 0.5 & 10.6 & -- & 11.1 & 472.3 & -- \\
\hline RABUT toe & 58.3 & -- & -- & -- & 485.7 & 0.5 & 11.0 & -- & 11.5 & 474.2 & -- \\
\hline Right abutment & 77.4 & -- & 497.6 & -- & 493.3 & -- & -- & -- & -- & -- & -- \\
\hline
\end{tabular}

1.Measured along the face of the most constricting side of the bridge.

2.Arbitrary datum for this study. 


\section{SELECTED REFERENCES}

Arcement, G.J., Jr., and Schneider, V.R., 1989, Guide for selecting Manning's roughness coefficients for natural channels and flood plains: U.S. Geological Survey Water-Supply Paper 2339, 38 p.

Barnes, H.H., Jr., 1967, Roughness characteristics of natural channels: U.S. Geological Survey Water-Supply Paper 1849,213 p.

Benson, M. A., 1962, Factors Influencing the Occurrence of Floods in a Humid Region of Diverse Terrain: U.S. Geological Survey WaterSupply Paper 1580-B, 64 p.

Brown, S.A. and Clyde, E.S., 1989, Design of riprap revetment: Federal Highway Administration Hydraulic Engineering Circular No. 11, Publication FHWA-IP-89-016, 156 p.

Federal Emergency Management Agency, 1988, Flood Insurance Study, Town of Jamaica, Windham County, Vermont: Washington, D.C., May 1988.

Federal Highway Administration, 1983, Runoff estimates for small watersheds and development of sound design: Federal Highway Administration Report FHWA-RD-77-158.

Federal Highway Administration, 1993, Stream Stability and Scour at Highway Bridges: Participant Workbook: Federal Highway Administration Report FHWA-HI-91-011.

Froehlich, D.C., 1989, Local scour at bridge abutments in Ports, M.A., ed., Hydraulic Engineering--Proceedings of the 1989 National Conference on Hydraulic Engineering: New York, American Society of Civil Engineers, p. 13-18.

Hayes, D.C.,1993, Site selection and collection of bridge-scour data in Delaware, Maryland, and Virginia: U.S. Geological Survey WaterResources Investigation Report 93-4017, 23 p.

Interagency Advisory Committee on Water Data, 1982, Guidelines for determining flood flow frequency: U.S. Geological Survey, Bulletin 17B of the Hydrology Subcommittee, 190 p.

Johnson, C.G. and Tasker, G.D.,1974, Progress report on flood magnitude and frequency of Vermont streams: U.S. Geological Survey OpenFile Report 74-130, 37 p.

Lagasse, P.F., Schall, J.D., Johnson, F., Richardson, E.V., Chang, F., 1995, Stream Stability at Highway Structures: Federal Highway Administration Hydraulic Engineering Circular No. 20, Publication FHWA-IP-90-014, 144 p.

Laursen, E.M., 1960, Scour at bridge crossings: Journal of the Hydraulics Division, American Society of Civil Engineers, v. 86, no. HY2, p. 39-53.

Potter, W. D., 1957a, Peak rates of runoff in the Adirondack, White Mountains, and Maine woods area, Bureau of Public Roads

Potter, W. D., 1957b, Peak rates of runoff in the New England Hill and Lowland area, Bureau of Public Roads

Richardson, E.V. and Davis, S.R., 1995, Evaluating scour at bridges: Federal Highway Administration Hydraulic Engineering Circular No. 18, Publication FHWA-IP-90-017, 204 p.

Richardson, E.V., Simons, D.B., and Julien, P.Y., 1990, Highways in the river environment: Federal Highway Administration Publication FHWA-HI-90-016.

Ritter, D.F., 1984, Process Geomorphology: W.C. Brown Co., Debuque, Iowa, 603 p.

Shearman, J.O., 1990, User's manual for WSPRO--a computer model for water surface profile computations: Federal Highway Administration Publication FHWA-IP-89-027, 187 p.

Shearman, J.O., Kirby, W.H., Schneider, V.R., and Flippo, H.N., 1986, Bridge waterways analysis model; research report: Federal Highway Administration Publication FHWA-RD-86-108, 112 p.

Talbot, A.N., 1887, The determination of water-way for bridges and culverts.

U.S. Geological Survey, 1986, Jamaica, Vermont 7.5 Minute Series quadrangle map: U.S. Geological Survey Topographic Maps, Scale $1: 24,000$. 


\section{APPENDIX A: \\ WSPRO INPUT FILE}




\section{WSPRO INPUT FILE}

GR

GR

GR

AS

GR

GR

GR

GR

GR

*

$\mathrm{N}$

SA

*

HP 1 BRIDG

HP 2 BRIDG

HP 1 APPRO

BRIDG
U.S. Geological Survey WSPRO Input File jama029.wSP

Hydraulic analysis for structure JAMATH00300029 Date: 23-JUN-97

TH030 crossing Ball Mountain Brook, in Jamaica, Vermont JRD
$\operatorname{EXITX} \quad-69 \quad 0$.

$-24.8,499.68$

$18.0,480.88$

$41.0,480.89$

$84.4,478.37$

$136.7,497.52$

0.075

FULLV 0

$-24.8,500.89$

$18.0,482.09$

$-13.4,496.90$

$0.0,488.35$

$4.6,483.82$

$20.8,481.39$

$30.4,481.62$

$38.9,481.01$

$52.2,482.14$

$62.1,481.08$

$76.1,483.32$

$79.7,488.84$

$111.1,500.16$

$126.7,498.73$

$149.6,506.27$

0.075

SRD

LSEL

XSSKEW

$0.0,496.92$

$19.4,482.40$

$38.7,483.25$

$75.5,493.25$

$0.0,496.92$

$\begin{array}{crrr}\text { BRTYPE } & \text { BRWDTH } & \text { EMBSS } & \text { EMBELV } \\ 3 & 16.7 & 2.1 & 491.8 \\ 0.075 & & & \end{array}$

RDWAY

SRD EMBWID IPAVE

14.02

$-328.1,513.86-257.0,506.25$

$0.1,500.44 \quad 0.1,500.95$

$81.9,500.77$

$103.6,501.41$

$-81.0,500.61$

$81.4,501.44$

$115.8,504.45$

$0.0,500.24$

$81.4,500.80$

$127.0,515.92$

APPRO $98 \quad 0$.

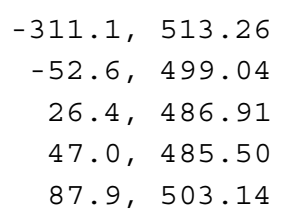

$-281.7,507.33$

$-17.9,498.86$

$-151.7,503.87$

$-57.7,501.93$

$34.2,486.19$

$0.0,489.52$

$19.3,489.77$

$37.7,485.93$

$43.7,485.78$

$52.6,486.16$

$61.7,486.64$

$71.4,489.64$

\section{$-17.9$}

488.941488 .94

$488.94 * * 3470$

$493.87 \quad 1493.87$ 


\section{APPENDIX B: \\ WSPRO OUTPUT FILE}


WSPRO OUTPUT FILE

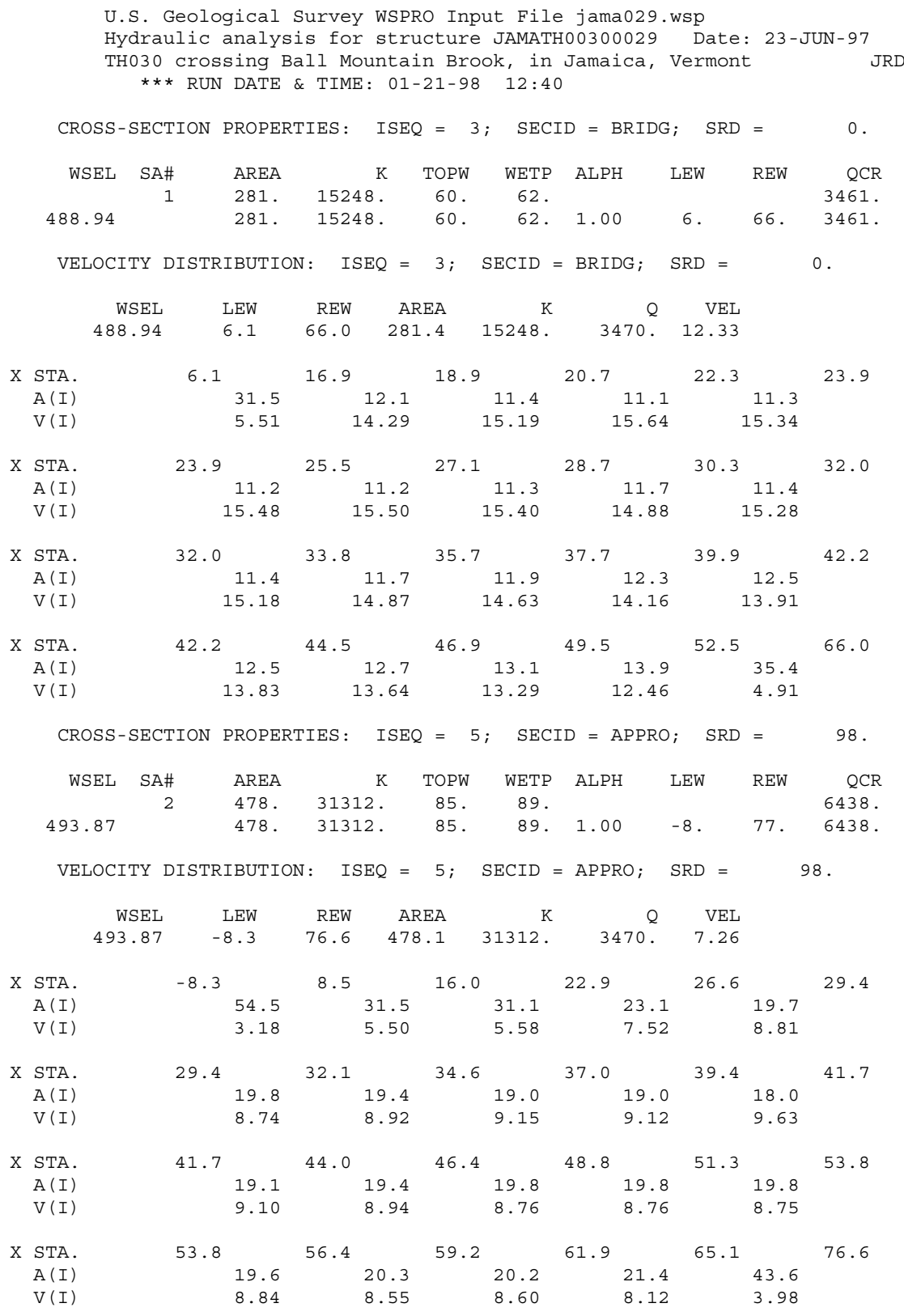


WSPRO OUTPUT FILE (continued)

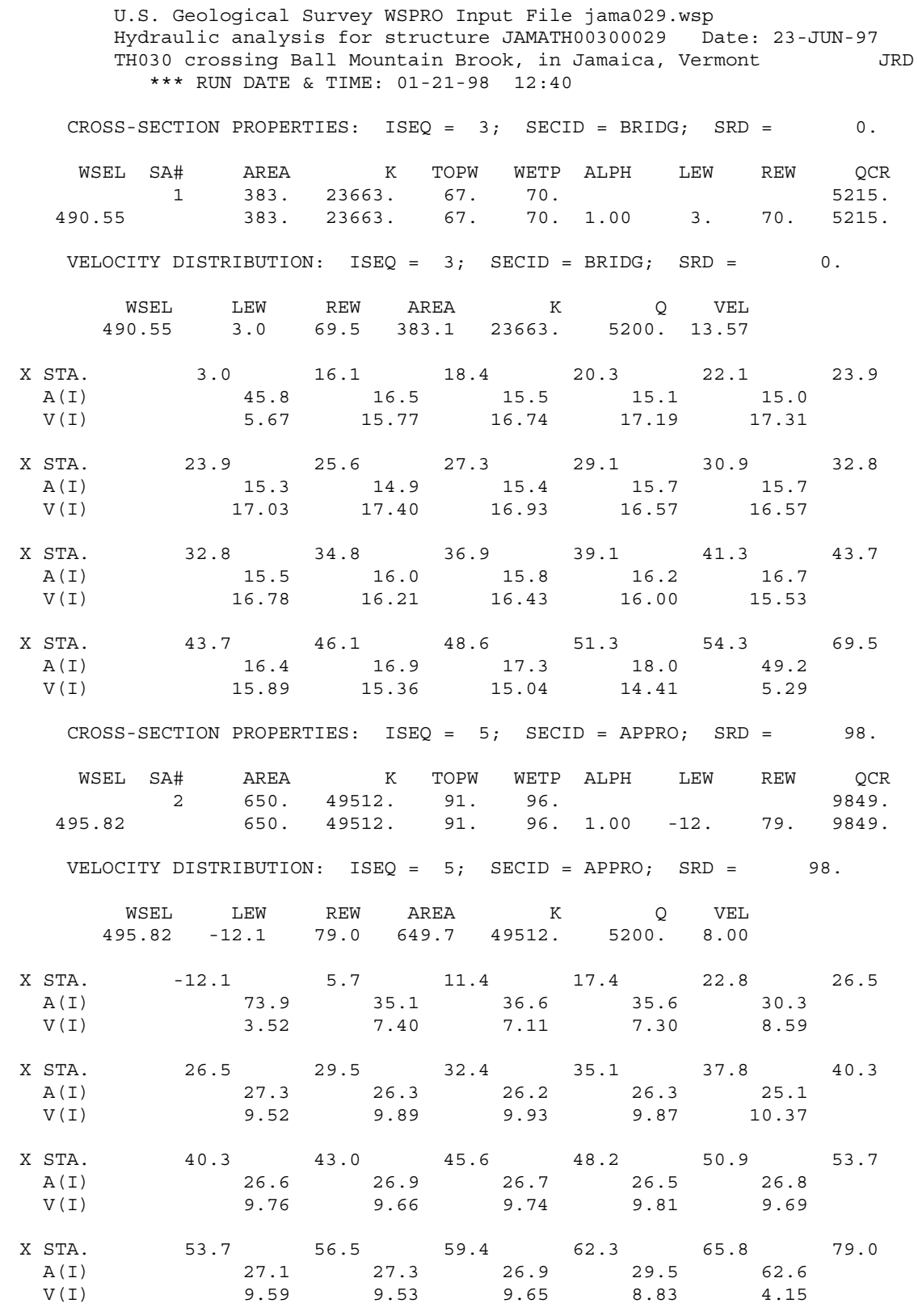


WSPRO OUTPUT FILE (continued)

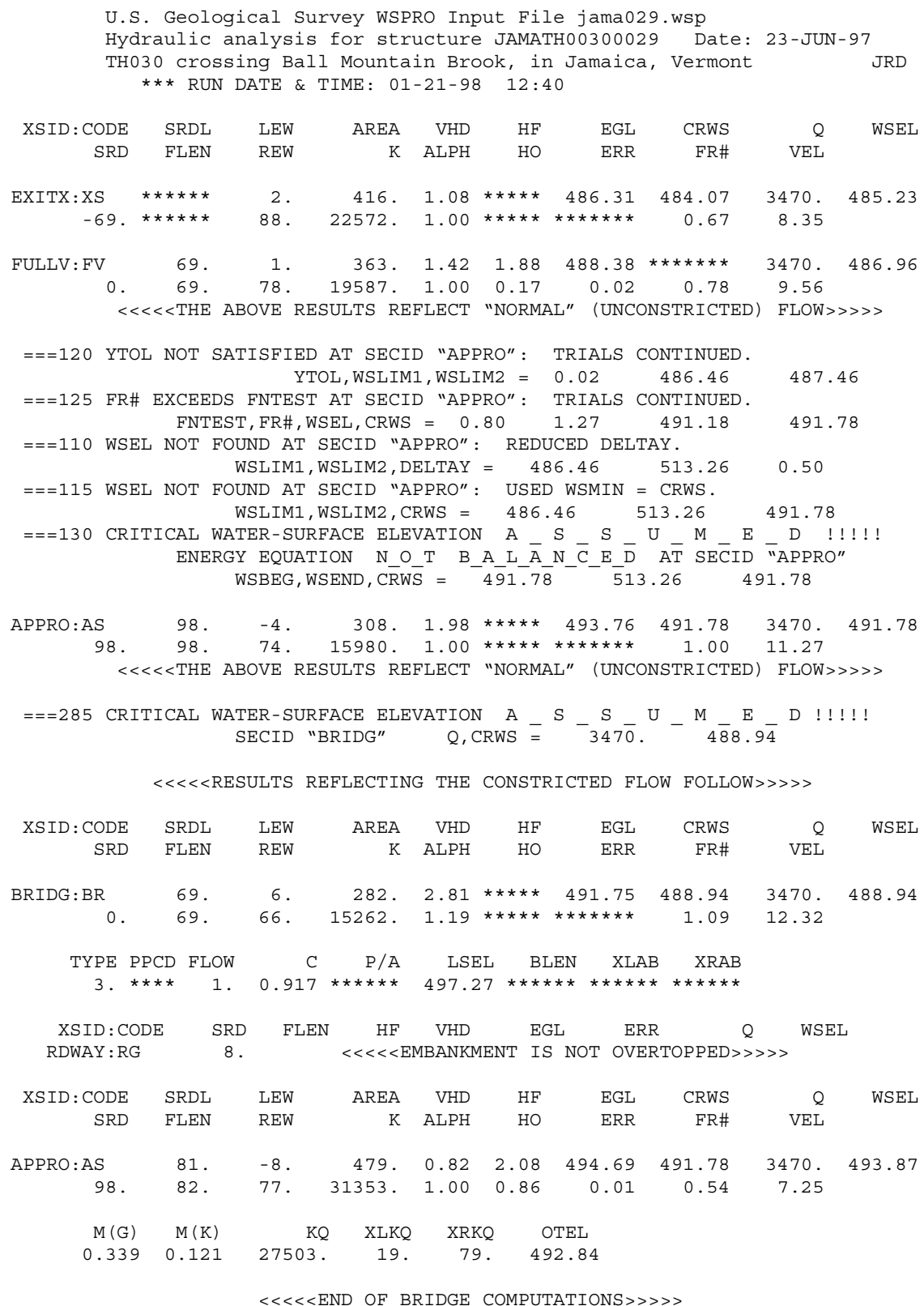

FIRST USER DEFINED TABLE.

\begin{tabular}{|c|c|c|c|c|c|c|c|c|}
\hline XSID: CODE & SRD & LEW & REW & $Q$ & $\mathrm{~K}$ & AREA & VEL & WSEL \\
\hline EXITX : XS & -69 & 2 . & 88. & 3470 . & 22572 . & 416. & 8.35 & 485.23 \\
\hline FULLV : FV & 0 . & 1. & 78. & 3470 . & 19587. & 363. & 9.56 & 486.96 \\
\hline BRIDG : BR & 0 . & 6. & 66. & 3470 . & 15262 . & 282 . & 12.32 & 488.94 \\
\hline RDWAY : RG & \multicolumn{3}{|c|}{ 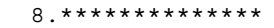 } & \multicolumn{3}{|c|}{ 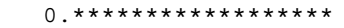 } & \multicolumn{2}{|c|}{$2.00 * \star \star * \star \star * \star *$} \\
\hline APPRO : AS & 98. & -8 . & 77. & 3470 . & 31353 . & 479 . & 7.25 & 493.87 \\
\hline XSID : CODE & XLKQ & XRKQ & & & & & & \\
\hline APPRO : AS & 19. & 79 . & 2750 & & & & & \\
\hline
\end{tabular}

SECOND USER DEFINED TABLE.

\begin{tabular}{|c|c|c|c|c|c|c|c|c|c|}
\hline XSID : CODE & CRWS & FR\# & YMIN & YMAX & $\mathrm{HF}$ & $\mathrm{HO}$ & VHD & EGL & WSEL \\
\hline EXITX:XS & 484.07 & 0.67 & 478.37 & $505.06 * *$ & 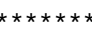 & $* \star \star \star * *$ & 1.08 & 486.31 & 35.23 \\
\hline FULLV : FV & $\star \star \star \star \star \star \star * \star * *$ & 78 & 481.01 & 506.27 & 1.88 & 0.17 & 1.42 & .38 & 96 \\
\hline BRID & 488.94 & 1.09 & 481.68 & $497.62 * *$ & $\star \star \star \star \star \star * *$ & $* * * * *$ & 2.81 & 491.75 & 488.94 \\
\hline$:$ RG & $\star \star \star \star \star * \star * *$ & $\star \star \star \star *$ & 500.24 & $92 * *$ & & & 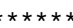 & $\star *$ & * \\
\hline APPRO : AS & 491.78 & 0.54 & 485.50 & 513.26 & 2.08 & 0.86 & 0.82 & 494.69 & 493.87 \\
\hline
\end{tabular}


WSPRO OUTPUT FILE (continued)

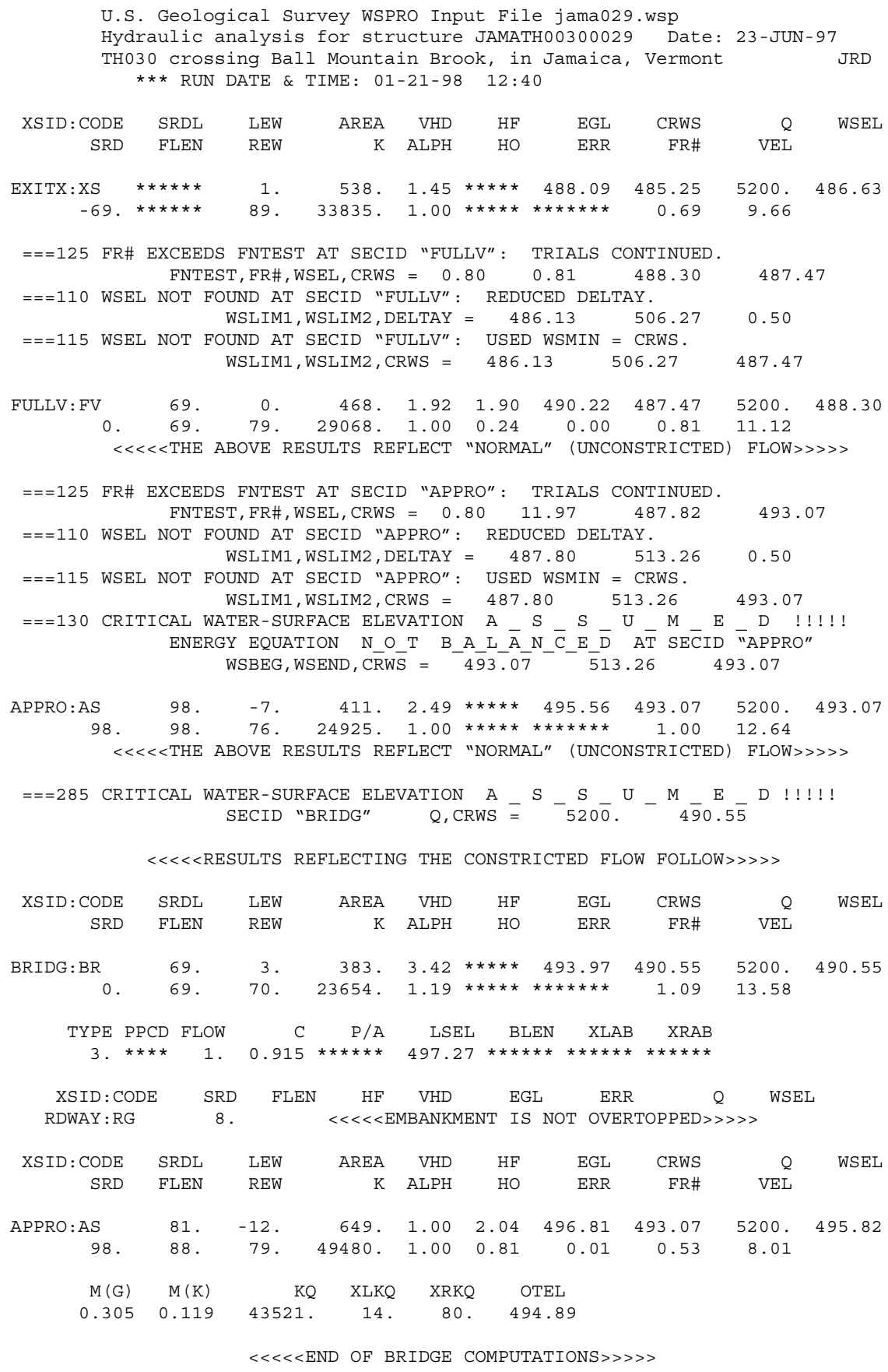

FIRST USER DEFINED TABLE.

\begin{tabular}{|c|c|c|c|c|c|c|c|c|}
\hline XSID : CODE & SRD & LEW & REW & $Q$ & K & AREA & VEL & WSEL \\
\hline EXITX:XS & -69. & 1 . & 89. & 5200. & 33835 . & 538. & 9.66 & 486.63 \\
\hline FULLV: FV & 0 . & 0. & 79. & 5200 . & 29068 & 468 & 11.12 & 488.30 \\
\hline BRIDG : BR & 0 . & 3 . & 70. & 5200. & 23654 . & 383. & 13.58 & 490.55 \\
\hline RDWAY : RG & \multicolumn{3}{|c|}{$8 . * * * * * * * * * * * * * *$} & \multicolumn{3}{|c|}{ 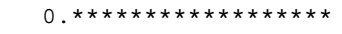 } & \multicolumn{2}{|c|}{$2.00 * * * * * * * *$} \\
\hline APPRO : AS & 98. & -12 & 79. & 5200. & 49480 & 649. & 8.01 & 495.82 \\
\hline XSID : CODE & XLKQ & XRKQ & & & & & & \\
\hline APPRO : AS & 14. & 80 . & 43521 & & & & & \\
\hline
\end{tabular}

SECOND USER DEFINED TABLE.

$\begin{array}{lcrrrrrrrr}\text { XSID }: \text { CODE } & \text { CRWS } & \text { FR\# } & \text { YMIN } & \text { YMAX } & \text { HF } & \text { HO } & \text { VHD } & \text { EGL } & \text { WSEL } \\ \text { EXITX:XS } & 485.25 & 0.69 & 478.37 & 505.06 * * * * * * * * * * & 1.45 & 488.09 & 486.63 \\ \text { FULLV : FV } & 487.47 & 0.81 & 481.01 & 506.27 & 1.90 & 0.24 & 1.92 & 490.22 & 488.30 \\ \text { BRIDG : BR } & 490.55 & 1.09 & 481.68 & 497.62 * * * * * * * * * * & 3.42 & 493.97 & 490.55 \\ \text { RDWAY : RG } & * * * * * * * * * * * * * * * & 500.24 & 515.92 * * * * * * * * * * * * * * * * * * * * * * * * * * * * * * * \\ \text { APPRO:AS } & 493.07 & 0.53 & 485.50 & 513.26 & 2.04 & 0.81 & 1.00 & 496.81 & 495.82\end{array}$




\section{APPENDIX C:}

\section{BED-MATERIAL PARTICLE-SIZE DISTRIBUTION}




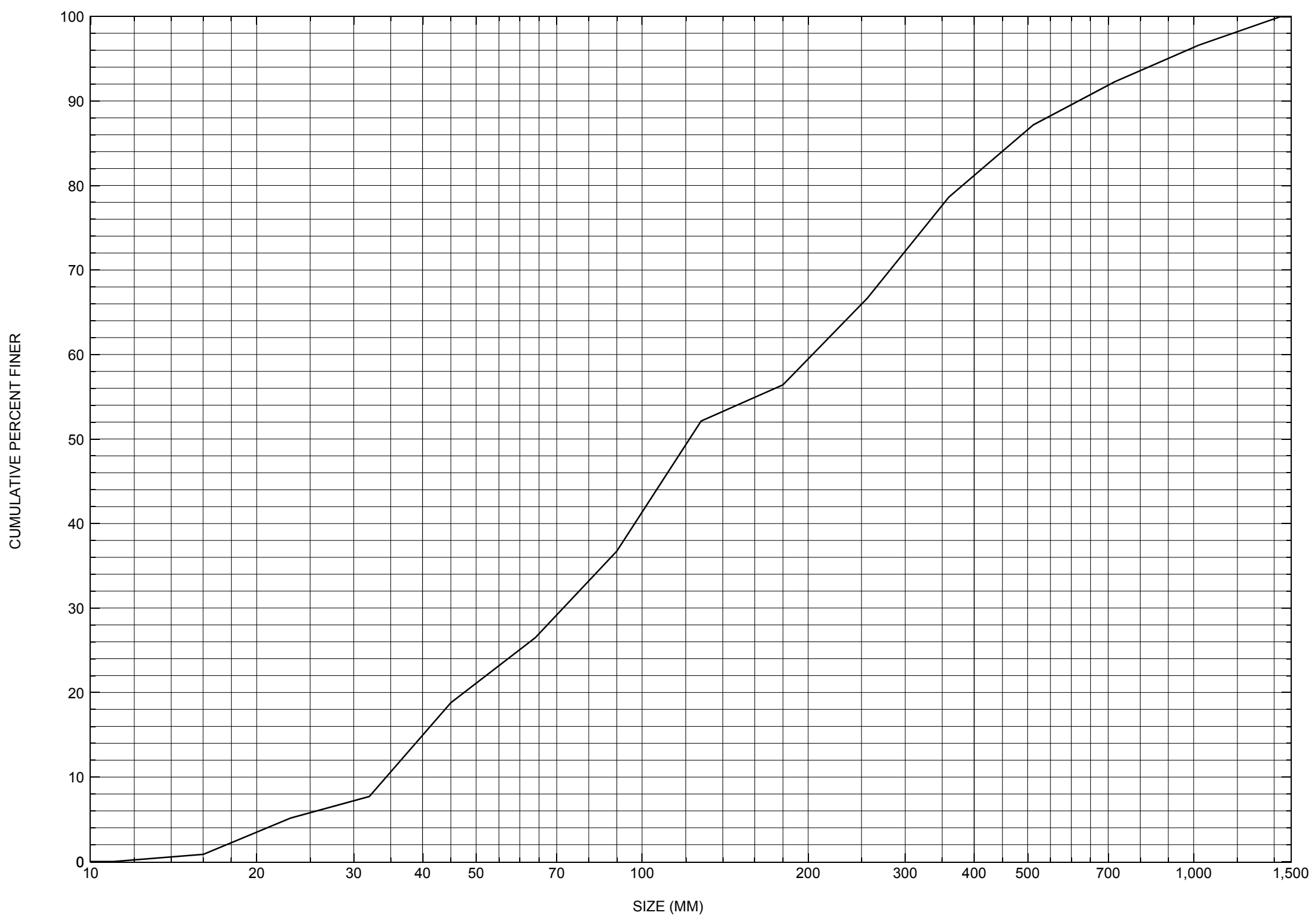

Appendix C. Bed material particle-size distribution for a pebble count in the channel approach of structure JAMATH00300029, in Jamaica, Vermont. 


\section{APPENDIX D: \\ HISTORICAL DATA FORM}




\section{Structure Number JAMATH00300029}

\section{General Location Descriptive}

Data collected by (First Initial, Full last name) $\mathbf{M}$. IVANOFF

Date $(M M / D D / Y Y) \_\mathbf{0 3} / \underline{\mathbf{3 0} /} \mathbf{9 5}$

Highway District Number (I - 2; nn) $\mathbf{0 2}$

Town (FIPS place code; I - 4; nnnnn) $\mathbf{3 6 1 7 5}$

Waterway (I - 6) BALL MOUNTAIN BROOK

Route Number $\underline{\text { TH030 }}$

Topographic Map Jamaica

Latitude (I - 16; nnnn.n) $\mathbf{4 3 0 4 2}$
County (FIPS county code; I - 3; nnn)

Mile marker (I - 11; nnn.nnn) $\mathbf{0 0 0 0 0 0}$

Road Name (I - 7): -

Vicinity (l - 9) 0.1 MI JCT TH 30 \& TH 27

Hydrologic Unit Code: $\mathbf{0 1 0 8 0 1 0 7}$

Longitude (i - 17; nnnnn.n) $\mathbf{7 2 5 0 8}$

\section{Select Federal Inventory Codes}

FHWA Structure Number (I - 8) 10130900291309

Maintenance responsibility $(I-21 ; n n)$

Year built (I - 27; YYYY) 1939

Average daily traffic, ADT (I - 29; nnnnnn) 000050

Year of ADT (I - 30; YY) $\mathbf{9 1}$

Opening skew to Roadway $(I-34 ; n n) \quad \mathbf{0 0}$

Operational status $(I-41 ; X) \underline{\mathbf{P}}$

Structure type (I- 43; nnn) $\mathbf{3 0 2}$

Approach span structure type (I - 44; nnn) $\mathbf{0 0 0}$

Number of spans (I - 45; nnn) $\mathbf{0 0 1}$

Number of approach spans (I - 46; nnnn) $\mathbf{0 0 0 0}$

Comments:

The structural inspection report of $09 / 15 / 93$ indicates the structure is a single span, steel beam type bridge with a timber deck. Both abutments are mortared stone with concrete bearing caps and backwalls. The right abutment is in generally good condition. New stone fill is in place along the left abutment wall. The waterway takes a moderate to sharp turn through the structure. The streambed consists of stone and boulders, with some gravel deposits. There is a large slope along the side of the river upstream from the right abutment.
Maximum span length (I - 48; nnnn) $\underline{\mathbf{0 0 8 0}}$

Structure length (I - 49; nnnnnn) $\underline{\mathbf{0 0 0 0 8 4}}$

Deck Width (I - 52; nn.n) 140

Channel \& Protection $(I-61 ; n) \underline{6}$

Waterway adequacy $(I-71 ; n) \underline{5}$

Underwater Inspection Frequency $(I-92 B ; X Y Y) \_$N

Year Reconstructed (I - 106) $\mathbf{0 0 0 0}$

Clear span (nnn.n ft) _

Vertical clearance from streambed (nnn.n ft) $\underline{\mathbf{0 1 3 . 5}}$

Waterway of full opening $\left(n n n . n \mathrm{ft}^{2}\right)$ 


\section{Bridge Hydrologic Data}

Is there hydrologic data available? $\underline{\mathbf{N}}$ if No, type ctrl-n $h \quad$ VTAOT Drainage area $\left(m i^{2}\right)$ : -

Terrain character:

Stream character \& type: -

Streambed material:

Discharge Data (cfs):

$$
\begin{aligned}
& Q_{2.33}- \\
& Q_{50}-
\end{aligned}
$$

Record flood date $(M M / D D / Y Y)$ :

Estimated Discharge (cfs): Ice conditions (Heavy, Moderate, Light) : -

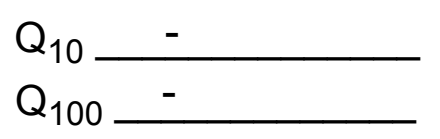

$$
\begin{aligned}
& Q_{25}- \\
& Q_{500}-
\end{aligned}
$$

Water surface elevation $(f t):-$

The stage increases to maximum highwater elevation (Rapidly, Not rapidly):

The stream response is (Flashy, Not flashy):

Describe any significant site conditions upstream or downstream that may influence the stream's stage: -

Watershed storage area (in percent): _ _ \%

The watershed storage area is: - (1-mainly at the headwaters; 2- uniformly distributed; 3-immediatly upstream oi the site)

Water Surface Elevation Estimates for Existing Structure:

\begin{tabular}{|l|l|l|l|l|l|}
\hline Peak discharge frequency & $Q_{2.33}$ & $Q_{10}$ & $Q_{25}$ & $Q_{50}$ & $Q_{100}$ \\
Water surface elevation (ft)) & - & - & - & - & - \\
Velocity (ft/sec) & - & - & - & - & - \\
\hline
\end{tabular}

Long term stream bed changes: -

Is the roadway overtopped below the $\mathrm{Q}_{100}$ ? (Yes, No, Unknown): $\mathbf{U}$ Frequency: Relief Elevation (ft): Discharge over roadway at $Q_{100}\left(f^{3} / \mathrm{sec}\right)$ :

Are there other structures nearby? (Yes, No, Unknown): $\underline{\mathbf{U}}$ Upstream distance (miles): Town: If No or Unknown, type ctrl-n os Highway No. : Structure No. : Year Built:

Clear span (ft): Clear Height $(f t)$ : Full Waterway $\left(f^{2}\right)$ : 
Downstream distance (miles): Town: Year Built:

Highway No. : Structure No. : Structure Type:

Clear span (ft): Clear Height $(f t)$ : Full Waterway $\left(f^{2}\right)$ : -

Comments:

\section{USGS Watershed Data}

Watershed Hydrographic Data

Drainage area $(D A) \underline{\mathbf{1 0 . 4 2}} \mathrm{mi}^{2}$ Lake/pond/swamp area 0.02 $\mathrm{mi}^{2}$

Watershed storage (ST) 0.2

Bridge site elevation 1496 $\mathrm{ft}$ $\%$

Main channel length 6.65 mi $10 \%$ channel length elevation 1555 $\mathrm{ft} \quad 85 \%$ channel length elevation $\mathrm{ft}$

Main channel slope (S) 138.23 $\mathrm{ft} / \mathrm{mi}$

Watershed Precipitation Data

Average site precipitation in Average headwater precipitation in

Maximum 2yr-24hr precipitation event $(I 24,2)$ in

Average seasonal snowfall (Sn) $\mathrm{ft}$ 


\section{Bridge Plan Data}

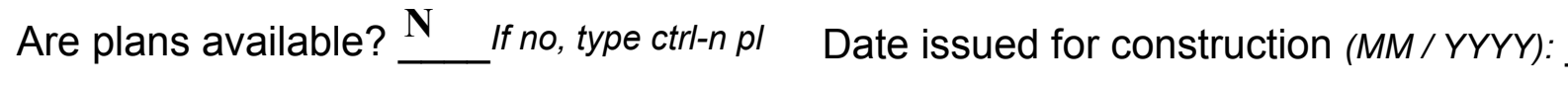

Project Number

Minimum channel bed elevation:

Low superstructure elevation: USLAB DSLAB USRAB DSRAB Benchmark location description:

NO BENCHMARK INFORMATION

Reference Point (MSL, Arbitrary, Other): Datum (NAD27, NAD83, Other):

Foundation Type: 4

If 1: Footing Thickness

If 2: Pile Type: (1-Wood; 2-Steel or metal; 3-Concrete)

If 3 : Footing bottom elevation:

Is boring information available? $\mathbf{N}$ Foundation Material Type: $\underline{3}$ (1-Spreadfooting; 2-Pile; 3- Gravity; 4-Unknown) Footing bottom elevation: -

Briefly describe material at foundation bottom elevation or around piles:

NO FOUNDATION MATERIAL INFORMATION

Comments:

The plan available is one page and provides no benchmark or footing information. 


\section{Cross-sectional Data}

Is cross-sectional data available? Yes If no, type ctrl-n xs

Source (FEMA, VTAOT, Other)? FEMA

Comments: The station and elevation measurements are in feet.

\begin{tabular}{|l|l|l|l|l|l|l|l|l|l|l|l|}
\hline Station & 511 & 512 & 534 & 554 & 564 & 579 & 586 & 589 & - & - & - \\
\hline Feature & LAB & - & - & - & - & - & - & RAB & - & - & - \\
\hline $\begin{array}{l}\text { Low cord } \\
\text { elevation }\end{array}$ & 1507.1 & $\mathbf{1 5 0 7 . 1}$ & $\mathbf{1 5 0 6 . 9}$ & $\mathbf{1 5 0 6 . 7}$ & $\mathbf{1 5 0 6 . 6}$ & $\mathbf{1 5 0 6 . 4}$ & $\mathbf{1 5 0 3 . 3}$ & $\mathbf{1 5 0 6 . 3}$ & - & - & - \\
\hline $\begin{array}{l}\text { Bed } \\
\text { elevation }\end{array}$ & - & $\mathbf{1 5 0 2 . 5}$ & $\mathbf{1 4 9 4 . 2}$ & $\mathbf{1 4 9 3 . 2}$ & $\mathbf{1 4 9 2 . 7}$ & $\mathbf{1 4 9 3 . 2}$ & $\mathbf{1 4 9 5 . 4}$ & - & - & - & - \\
\hline $\begin{array}{l}\text { Low cord to } \\
\text { bed length }\end{array}$ & - & 4.6 & 12.7 & $\mathbf{1 3 . 5}$ & $\mathbf{1 3 . 9}$ & $\mathbf{1 3 . 2}$ & $\mathbf{1 0 . 9}$ & - & - & - & - \\
\hline Station & - & - & - & - & - & - & - & - & - & - & - \\
\hline Feature & - & - & - & - & - & - & - & - & - & - & - \\
\hline $\begin{array}{l}\text { Low cord } \\
\text { elevation }\end{array}$ & - & - & - & - & - & - & - & - & - & - & - \\
\hline $\begin{array}{l}\text { Bed } \\
\text { elevation }\end{array}$ & - & - & - & - & - & - & - & - & - & - & - \\
\hline $\begin{array}{l}\text { Low cord to } \\
\text { bed length }\end{array}$ & - & - & - & - & - & - & - & - & - & - & - \\
\hline
\end{tabular}

Source (FEMA, VTAOT, Other)?

Comments: -

\begin{tabular}{|l|l|l|l|l|l|l|l|l|l|l|l|}
\hline Station & - & - & - & - & - & - & - & - & - & - & - \\
\hline Feature & - & - & - & - & - & - & - & - & - & - & - \\
\hline $\begin{array}{l}\text { Low cord } \\
\text { elevation }\end{array}$ & - & - & - & - & - & & - & - & - & - & - \\
\hline $\begin{array}{l}\text { Bed } \\
\text { elevation }\end{array}$ & - & - & - & - & - & - & - & - & - & - & - \\
\hline $\begin{array}{l}\text { Low cord to } \\
\text { bed length }\end{array}$ & - & - & - & - & - & - & - & - & - & - & - \\
\hline Station & - & - & - & - & - & - & - & - & - & - & - \\
\hline Feature & - & - & - & - & - & - & - & - & - & - & - \\
\hline $\begin{array}{l}\text { Low cord } \\
\text { elevation }\end{array}$ & - & - & - & - & - & - & - & - & - & - & - \\
\hline $\begin{array}{l}\text { Bed } \\
\text { elevation }\end{array}$ & - & - & - & - & - & - & - & - & - & - & - \\
\hline $\begin{array}{l}\text { Low cord to } \\
\text { bed length }\end{array}$ & - & - & - & - & - & - & - & - & - & - & - \\
\hline
\end{tabular}




\section{APPENDIX E: \\ LEVEL I DATA FORM}


U. S. Geological Survey

Bridge Field Data Collection and Processing Form

Qa/Qc Check by: $\underline{\mathbf{R B}}$ Date: $11 / 6 / 96$

\section{Structure Number}

JАMATH00300029

Computerized by: $\underline{\mathbf{R B}}$ Date: $\underline{11 / 7 / 96}$

Reviewd by:

JD Date: 9/2/97

\section{A. General Location Descriptive}

1. Data collected by (First Initial, Full last name) $\mathbf{J}$. DEGNAN

Date $(M M / D D / Y Y)$

08 / 12 / 1996

2. Highway District Number $\mathbf{0 2}$

Mile marker 0000

County WINDHAM (025)

Waterway ( $($ - 6) BALL MOUNTAIN BROOK

Route Number TH030

Town JAMAICA (36175)

Road Name -

Hydrologic Unit Code: $\mathbf{0 1 0 8 0 1 0 7}$

3. Descriptive comments:

This wood decked bridge is 0.1 miles from the junction of TH 30 and TH 27.

\section{B. Bridge Deck Observations}
4. Surface cover... LBUS 6
RBUS 6
LBDS 6
RBDS 6
Overall 6

(2b us,ds,lb,rb: 1- Urban; 2- Suburban; 3- Row crops; 4- Pasture; 5- Shrub- and brushland; 6- Forest; 7- Wetland)
5. Ambient water surface... US 2
UB 2
DS $\underline{2}$
(1- pool; 2- riffle)

6. Bridge structure type 1 (1- single span; 2- multiple span; 3- single arch; 4- multiple arch; 5-cylindrical culvert; 6- box culvert; or 7- other)
7. Bridge length $\underline{84}$
(feet)
Span length $\underline{\mathbf{8 0}}$
(feet)
Bridge width 14 (feet)

\section{Road approach to bridge:}
8. LB 2 RB 1
( 0 even, 1- lower, 2- higher)
9. LB_2
RB $\underline{2}$
(1-Paved, 2- Not paved)

10. Embankment slope (run / rise in feet / foot)

US left --

US right --

\begin{tabular}{|c|c|c|c|}
\hline \multicolumn{2}{|c|}{ Protection } & \multirow{2}{*}{ 13.Erosion } & 14.Severity \\
\hline 11.Type & 12.Cond. & $\mathbf{0}$ & - \\
\hline $\mathbf{1}$ & $\mathbf{1}$ & $\mathbf{0}$ & - \\
$\mathbf{0}$ & - & $\mathbf{0}$ & - \\
\hline $\mathbf{0}$ & - & $\mathbf{0}$ & - \\
\hline $\mathbf{1}$ & $\mathbf{1}$ & $\mathbf{0}$ & - \\
\hline
\end{tabular}

Bank protection types: 0- none; 1- < 12 inches,

2- $<36$ inches; $3-<48$ inches;

4- < 60 inches; 5- wall / artificial levee

Bank protection conditions: 1- good; 2- slumped;

3- eroded; 4- failed

Erosion: 0 - none; 1- channel erosion; 2 -

road wash; 3- both; 4- other

Erosion Severity: 0 - none; 1- slight; 2- moderate; 3- severe

Channel approach to bridge (BF):

15. Angle of approach: $\mathbf{2 5}$

16. Bridge skew: $\mathbf{0}$

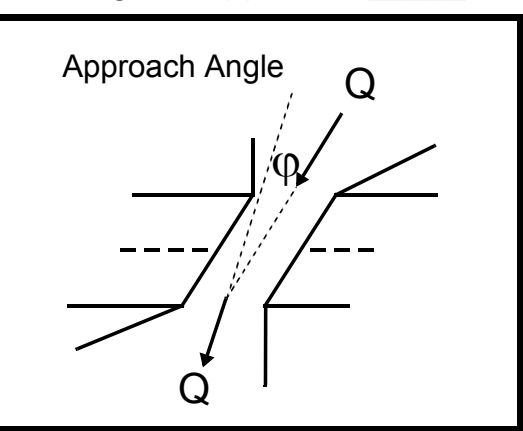

17. Channel impact zone 1:

Where? RB (LB, RB)

Range? 170 feet $\underline{\mathbf{U S}}$

Channel impact zone 2 :

Where? LB $(L B, R B)$

Range? $\underline{\mathbf{0}}$ feet US

Impact Severity: 0- none to very slight; 1- Slight; 2- Moderate; 3- Severe
Bridge Skew Angle

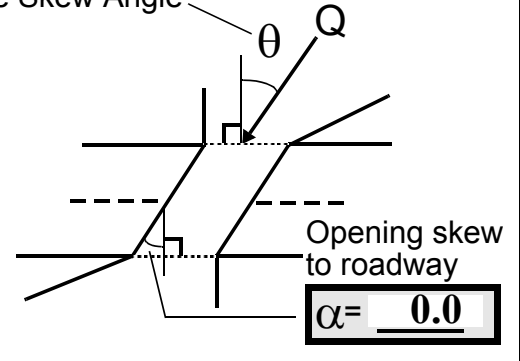

\section{Exist? $\mathbf{Y}(Y$ or $N)$}

Severity 2

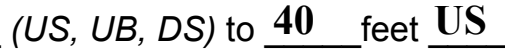

Exist? Y $(Y$ or $N)$

Severity 1

, UB, DS) to $\underline{90 \quad \text { feet }}$ DS 
18. Bridge Type: $\mathbf{1 b}$

1a- Vertical abutments with wingwalls

$1 \mathrm{~b}$ - Vertical abutments without wingwalls

2- Vertical abutments and wingwalls, sloping embankment Wingwalls perpendicular to abut. face

3- Spill through abutments

4- Sloping embankment, vertical wingwalls and abutments

Wingwall angle less than $90^{\circ}$.

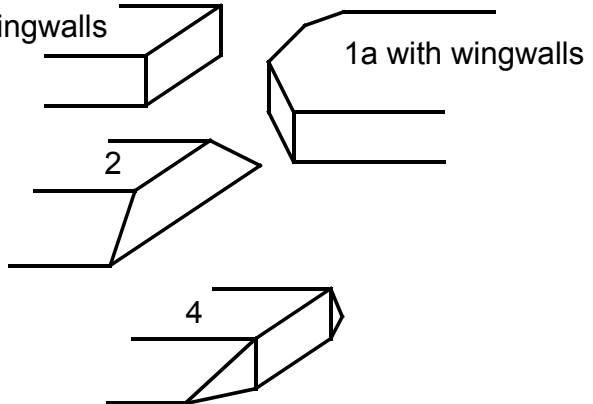

19. Bridge Deck Comments (surface cover variations, measured bridge and span lengths, bridge type variations, approach overflow width, etc.)

4. The surface cover on the US left bank and the DS left bank is lawn beyond the trees that are along the bank.

7. Values are from the VTAOT files. Measured bridge dimensions match those in the historical form. 17. A third severe impact zone is on the left bank just beyond the DS confluence. The channel impacts bedrock and switches direction by 90 degrees.

\section{Upstream Channel Assessment}

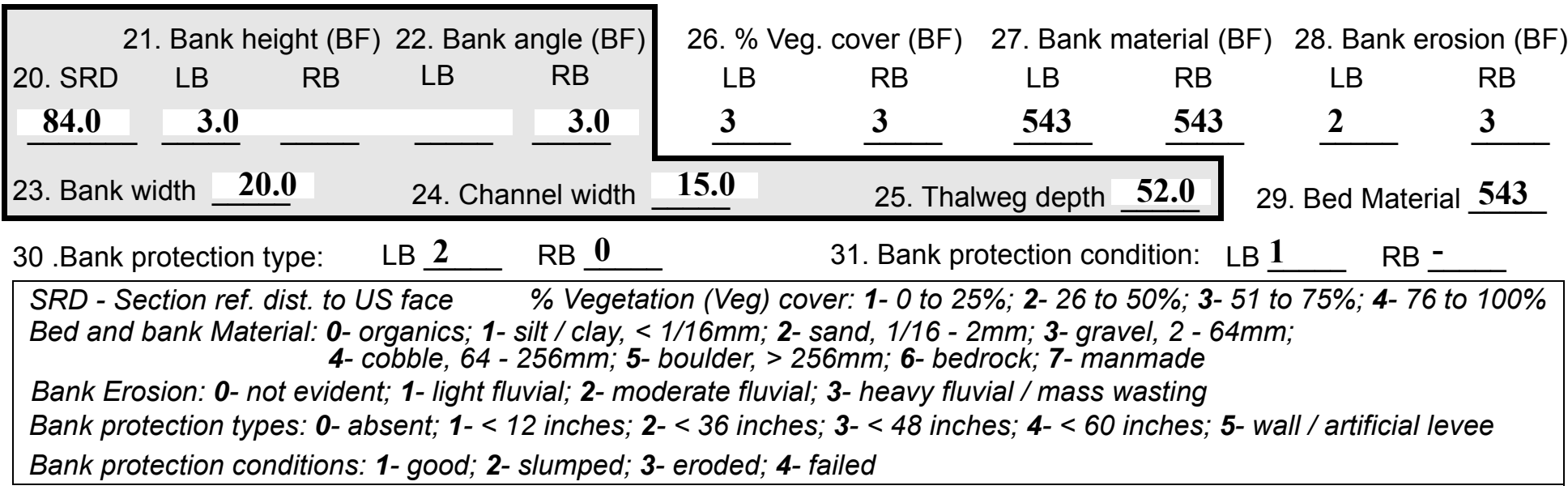

32. Comments (bank material variation, minor inflows, protection extent, etc.):

26. A land slide has occurred along the right bank, where the vegetation cover is between $0 \%$ and $25 \%$. The cover noted above takes into account the undisturbed forest on the overbank. The right bank is also vegetated close to the bridge which helps to stabilize it.

30. The left bank protection extends from $25 \mathrm{ft}$ US to $0 \mathrm{ft}$ US. It is dumped stone. 
33.Point/Side bar present? $\mathbf{Y}(Y$ or $N$. if $N$ type ctrl-n pb)34. Mid-bar distance: $\mathbf{0}$

35. Mid-bar width: 20

36. Point bar extent: 90 feet $\underline{\text { US }}$

(US, UB) to $\mathbf{0}$ feet DS

(US, UB, DS) positioned $\mathbf{6 0}$

\%LB to $100 \%$ RB

37. Material: $\mathbf{4 3 5}$

38. Point or side bar comments (Circle Point or Side; Note additional bars, material variation, status, etc.):

There is an additional point bar positioned $0 \% \mathrm{LB}$ to $40 \% \mathrm{RB}$ with a mid-bar distance of $160 \mathrm{ft}$ US extending from $175 \mathrm{ft}$ US to $140 \mathrm{ft}$ US. It consists of cobble, gravel and boulder and is $15 \mathrm{ft}$ wide at mid-bar.

39. Is a cut-bank present? $\mathbf{Y}$ (Y or if $N$ type ctrl-n cb)

40. Where? $\underline{\mathbf{R B}}$ (LB or $R B)$

41. Mid-bank distance: 110

42. Cut bank extent: 175 feet $\underline{\text { US }}$ (US, UB) to 40 feet $\underline{\mathbf{U S}}$ (US, UB, DS)

43. Bank damage: 2

(1- eroded and/or creep; 2- slip failure; 3- block failure)

44. Cut bank comments (eg. additional cut banks, protection condition, etc.):

\section{Is channel scour present? $\mathbf{Y}$ ( $Y$ or if $N$ type ctrl-n cs)}

46. Mid-scour distance: 55

47. Scour dimensions: Length $\mathbf{1 5}$

Width 10

Depth : $\underline{\mathbf{2 . 5}}$

Position $\mathbf{2 5} \%$ LB to $\mathbf{8 0}$

$\% \mathrm{RB}$

48. Scour comments (eg. additional scour areas, local scouring process, etc.):

This scour hole is caused by large boulders constricting flow. There are other areas of local scour around boulders. Assumed thalweg depth is $0.5 \mathrm{ft}$.

49. Are there major confluences? $\mathbf{N}$

51. Confluence 1: Distance Confluence 2: Distance -

52. Enters on -

Enters on - $\quad(L B$ or $R B)$

54. Confluence comments (eg. confluence name):

NO MAJOR CONFLUENCES
50. How many? -

53. Type(1- perennial; 2- ephemeral)

Type (1-perennial; 2- ephemeral)

\section{Under Bridge Channel Assessment}

55. Channel restraint (BF)? LB 2

\begin{tabular}{|ccccc}
\hline \multicolumn{2}{|c}{ 56. Height (BF) } & \multicolumn{3}{c}{57 Angle (BF) } \\
LB & RB & & LB & RB \\
35.5 & & & $\mathbf{0 . 5}$ & \\
\hline
\end{tabular}
(1- natural bank; 2- abutment; 3- artificial levee)

58. Bank width (BF) 59. Channel width (Amb) -

61. Material (BF)

LB RB

$2 \quad 7$
62. Erosion (BF)

LB RB

7

63. Bed Material -

Bed and bank Material: 0- organics; 1- silt / clay, < 1/16mm; 2- sand, 1/16 - 2mm; 3- gravel, 2 - 64mm; 4- cobble, 64 - 256mm; 5- boulder, > 256mm; 6- bedrock; 7- manmade

Bank Erosion: 0- not evident; 1- light fluvial; 2- moderate fluvial; 3- heavy fluvial / mass wasting

64. Comments (bank material variation, minor inflows, protection extent, etc.):

543 
65. Debris and Ice Is there debris accumulation?

$(Y$ or $N)$ 66. Where? $\underline{Y}$

(1- Upstream; 2- At bridge; 3- Both)

67. Debris Potential $\underline{3}$

( 1-Low; 2- Moderate; 3- High)

68. Capture Efficiency 3

(1-Low; 2- Moderate; 3- High)

69. Is there evidence of ice build-up? 1 (Y or N)

Ice Blockage Potential $\mathbf{N}$

(1-Low; 2- Moderate; 3- High)

70. Debris and Ice Comments:

1

The wide opening and high deck protect this bridge from debris and ice, but the sharp channel bends US and DS could cause blockage.

\begin{tabular}{|l|c|c|c|c|c|c|c|c|}
\hline Abutments & $\begin{array}{c}\text { 71. Attack } \\
\angle \text { (BF) }\end{array}$ & $\begin{array}{c}\text { 72. Slope } \angle \\
\text { (Qmax) }\end{array}$ & $\begin{array}{c}\text { 73. Toe } \\
\text { loc. (BF) }\end{array}$ & $\begin{array}{c}\text { 74. Scour } \\
\text { Condition }\end{array}$ & $\begin{array}{c}75 . \text { Scour } \\
\text { depth }\end{array}$ & $\begin{array}{c}\text { 76. Exposure } \\
\text { depth }\end{array}$ & 77. Material & 78. Length \\
\hline LABUT & & $\mathbf{0}$ & $\mathbf{9 0}$ & $\mathbf{2}$ & $\mathbf{0}$ & - & - & $\mathbf{9 0 . 0}$ \\
\hline RABUT & $\mathbf{2}$ & $\mathbf{0}$ & $\mathbf{9 0}$ & & & $\mathbf{0}$ & $\mathbf{0}$ & $\mathbf{7 7 . 5}$ \\
\hline
\end{tabular}

Pushed: $L B$ or RB

Toe Location (Loc.): 0- even, 1- set back, 2- protrudes

Scour cond.: 0- not evident; 1- evident (comment); 2- footing exposed; 3-undermined footing; 4- piling exposed; 5- settled; 6- failed

Materials: 1- Concrete; 2- Stone masonry or drywall; 3- steel or metal; 4- wood

79. Abutment comments (eg. undermined penetration, unusual scour processes, debris, etc.):

80. Wingwalls:

Exist? Material? Scour Scour Exposure $\begin{aligned} & 81 . \\ & \text { Angle? Length? }\end{aligned}$ Condition? depth? depth?

USLWW:

77.5

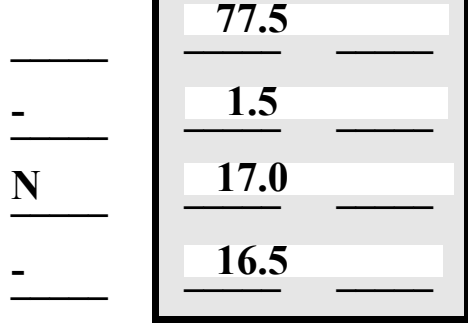

Wingwall materials: 1- Concrete; 2- Stone masonry or drywall; 3- steel or metal; 4- wood

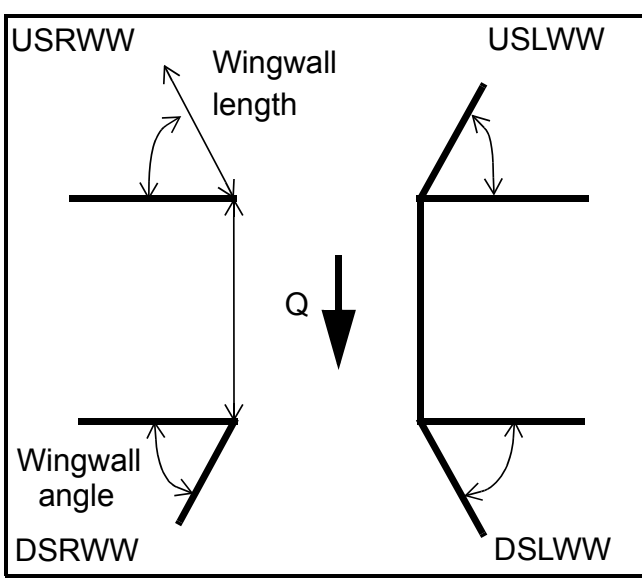

82. Bank / Bridge Protection:

\begin{tabular}{|l|l|l|l|l|l|l|l|c|}
\hline Location & USLWW & USRWW & LABUT & RABUT & LB & RB & DSLWW & DSRWW \\
\hline Type & - & - & N & - & - & - & $\mathbf{1}$ & $\mathbf{1}$ \\
\hline Condition & N & - & - & - & - & - & $\mathbf{1}$ & $\mathbf{1}$ \\
\hline Extent & - & - & - & - & - & $\mathbf{2}$ & $\mathbf{2}$ & - \\
\hline
\end{tabular}

Bank / Bridge protection types: 0- absent; 1- < 12 inches; 2- < 36 inches; 3- < 48 inches; 4- < 60 inches; 
83. Wingwall and protection comments (eg. undermined penetration, unusual scour processes, etc.):

-
-
-
-
-
-
-
-
-
-

\section{Piers:}

84. Are there piers? Th (Y or if N type ctrl-n pr)

\begin{tabular}{|l|l|l|l|l|l|l|l|}
\hline \multirow{2}{*}{$\begin{array}{l}85 . \\
\text { Pier no. }\end{array}$} & \multicolumn{3}{|c|}{ width (w) feet } & \multicolumn{3}{c|}{ elevation (e) feet } \\
\cline { 2 - 9 } & w1 & w2 & w3 & e@w1 & e@w2 & e@w3 \\
\hline Pier 1 & - & - & - & - & - & - \\
\hline Pier 2 & - & - & - & - & - & - \\
\hline Pier 3 & - & - & - & - & - & - \\
\hline Pier 4 & - & - & - & - & - & - \\
\hline
\end{tabular}

\begin{tabular}{|l|l|l|l|l|}
\hline Level 1 Pier Descr. & \multicolumn{1}{|c|}{1} & \multicolumn{1}{|c|}{2} & \multicolumn{1}{|c|}{3} & \multicolumn{1}{|c|}{4} \\
\hline 86. Location (BF) & e right & protec- & left & throug \\
\hline 87. Type & abut & tion & bank & h \\
\hline 88. Material & ment & is & pro- & slope \\
\hline 89. Shape & pro- & dum & tec- & s in \\
\hline 90. Inclined? & tec- & ped & tion. & front \\
\hline 91. Attack $\angle$ (BF) & tion & stone & This & of \\
\hline 92. Pushed & is rip & con- & pro- & each \\
\hline 93. Length (feet) & - & - & - & - \\
\hline 94. \# of piles & rap. & tinu- & tec- & abut \\
\hline 95. Cross-members & The & ing & tion & ment \\
\hline 96. Scour Condition & left & from & form & • \\
\hline 97. Scour depth & abut & the & s & \\
\hline 98. Exposure depth & ment & US & spill- & \\
\hline
\end{tabular}

LFP, LTB, LB, MCL, MCM, MCR, RB, RTB, RFP

1- Solid pier, 2-column, 3- bent

1-Wood; 2- concrete; 3- metal; 4- stone

1- Round; 2- Square; 3- Pointed

Y-yes; $N$ - no

$L B$ or $R B$

0- none; 1- laterals; 2- diagonals; 3- both

0- not evident; 1- evident (comment);

2- footing exposed; 3- piling exposed;

4- undermined footing; 5- settled; 6- failed 
99. Pier comments (eg. undermined penetration, protection and protection extent, unusual scour processes, etc.):

$\mathbf{N}$

100.

\section{E. Downstream Channel Assessment}

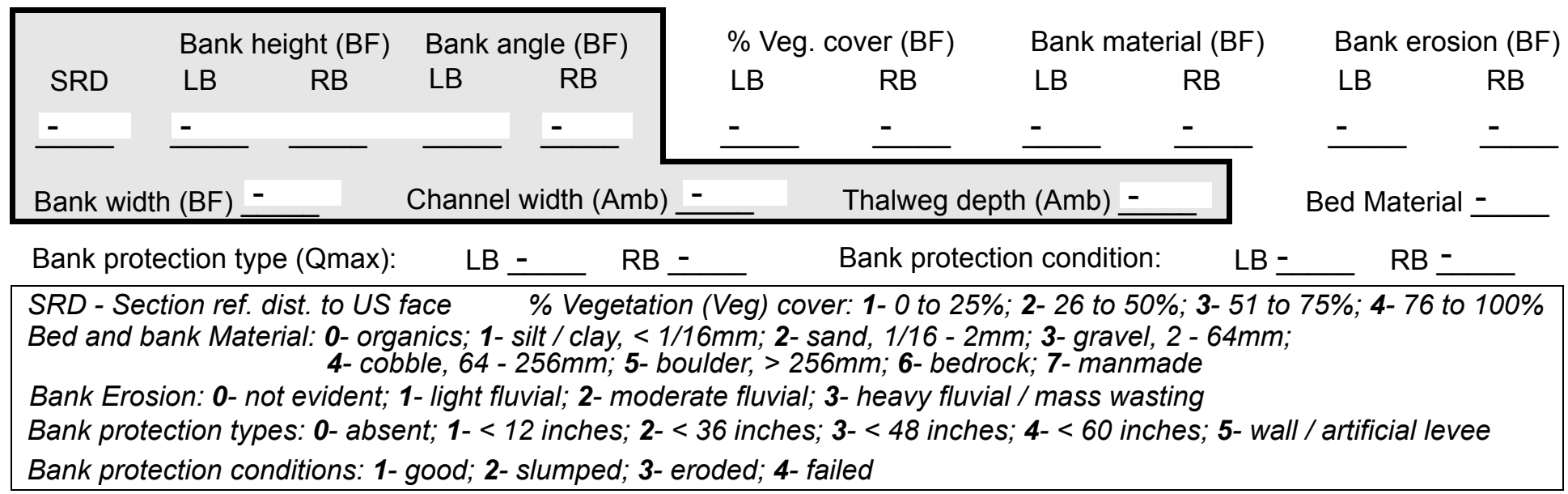

Comments (eg. bank material variation, minor inflows, protection extent, etc.):$$
-
$$$$
-
$$

$-$

$-$

$-$

$-$

$-$

$-$

$-$

$-$

$-$

$-$

$-$

$-$

$-$

\section{Is a drop structure present? __ ( $Y$ or $N$, if $N$ type ctrl-n ds) 102. Distance: ___ feet}

103. Drop: -_ feet 104. Structure material: ___ (1- steel sheet pile; 2- wood pile; 3- concrete; 4- other)

105. Drop structure comments (eg. downstream scour depth):

$-$

-

$-$

-

-

- 
106. Point/Side bar present? (Y or $N$. if $N$ type ctrl-n pb)Mid-bar distance:

Mid-bar width: -

Point bar extent: feet -

(US, UB, DS) to feet (US, UB, DS) positioned $\%$ LB to $\% R B$ Material:

Point or side bar comments (Circle Point or Side; note additional bars, material variation, status, etc.):

$-$

\section{NO PIERS}

Is a cut-bank present?

Cut bank extent: feet (US, UB, DS) to feet Where? (LB or $R B)$ Mid-bank distance:

Bank damage: (1- eroded and/or creep; 2- slip failure; 3- block failure)

Cut bank comments (eg. additional cut banks, protection condition, etc.): 3

3

435

435

Is channel scour present? 2 ( 2 or if $N$ type ctrl-n cs) Mid-scour distance: 2 Scour dimensions: Length $\underline{543}$ Width $\underline{2}$ Depth: $\underline{2}$ Positioned 1 _LB to 3 \%RB Scour comments (eg. additional scour areas, local scouring process, etc.):

The left bank protection is dumped stone continuing from the left abutment and extending to $20 \mathrm{ft}$ DS. The right bank protection runs along the base of the road embankment and goes from the right abutment to $130 \mathrm{ft}$ DS. At $70 \mathrm{ft}$ DS it has been eroded and at $88 \mathrm{ft}$ DS it becomes a stone wall.

Are there major confluences? Confluence 1: Distance Confluence 2: Distance Confluence comments (eg. confluence name): (Y or if $N$ type ctrl-n mc)

Enters on (LB or $R B)$ ( $L B$ or $R B)$

Enters on
How many?

Type (1-perennial; 2- ephemeral)

Type (1-perennial; 2- ephemeral)

\section{F. Geomorphic Channel Assessment}

107. Stage of reach evolution
1- Constructed

2- Stable

3- Aggraded

4- Degraded

5- Laterally unstable

6- Vertically and laterally unstable 
108. Evolution comments (Channel evolution not considering bridge effects; See HEC-20, Figure 1 for geomorphic descriptors):

$\mathbf{N}$

$-$

NO DROP STRUCTURE

$\mathbf{Y}$

190

45

40

DS 


\begin{tabular}{|c|c|c|c|}
\hline \multicolumn{4}{|c|}{ 109. G. Plan View Sketch } \\
\hline $\begin{array}{l}\text { point bar } \\
\text { cut-bank } \\
\text { scour hole }\end{array}$ & debris & $\begin{array}{l}\text { flow } \stackrel{Q}{\longrightarrow} \\
\text { cross-section }+|+|+1 \\
\text { ambient channel }\end{array}$ & $\begin{array}{l}\text { stone wall } \square \square \square \square \square \\
\text { other wall } \square\end{array}$ \\
\hline
\end{tabular}


APPENDIX F:

SCOUR COMPUTATIONS 


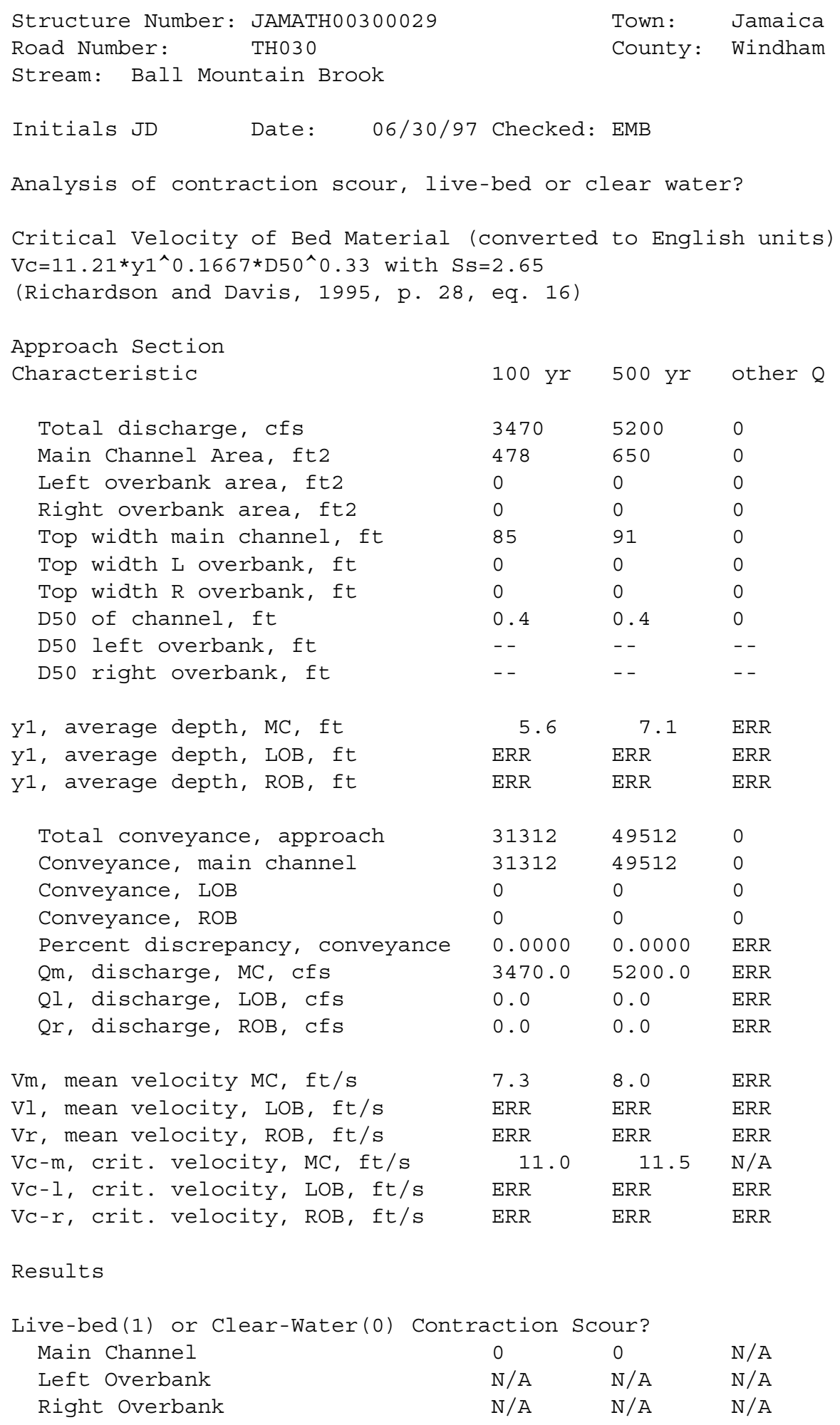


Clear water Contraction Scour in MAIN CHANNEL

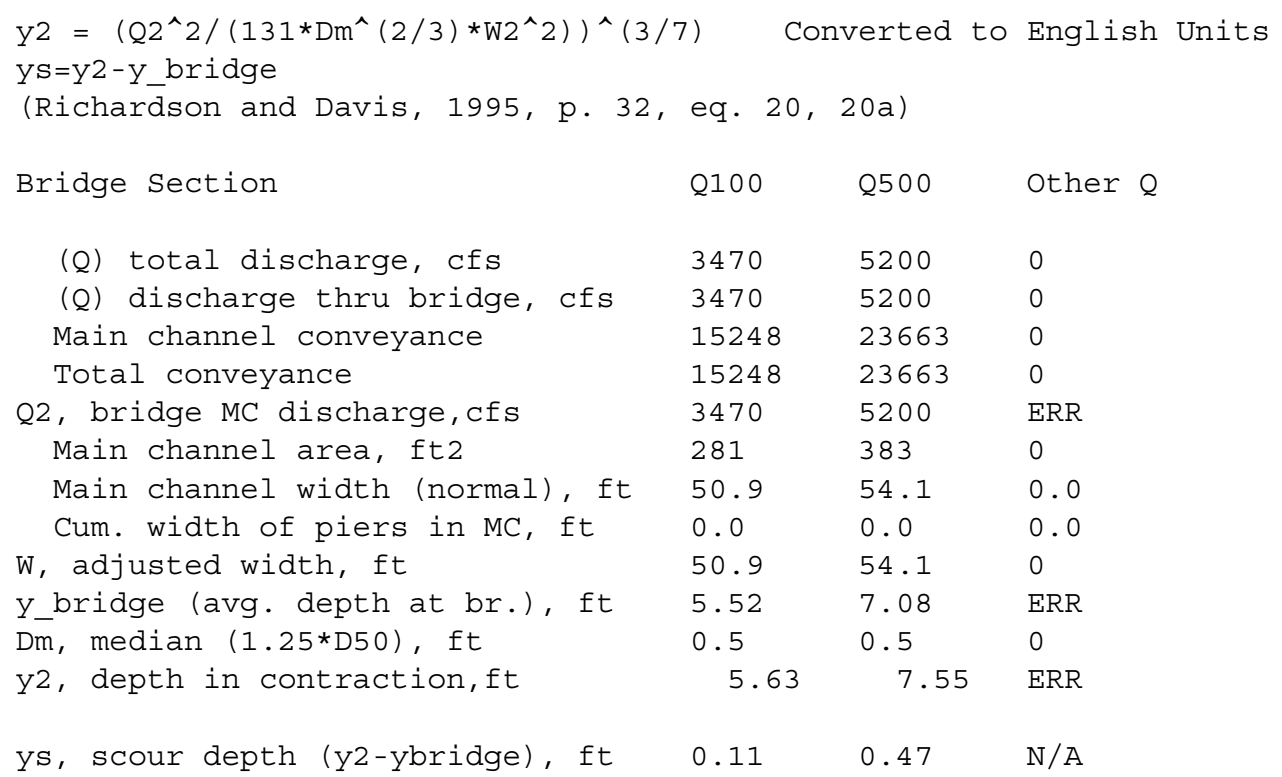

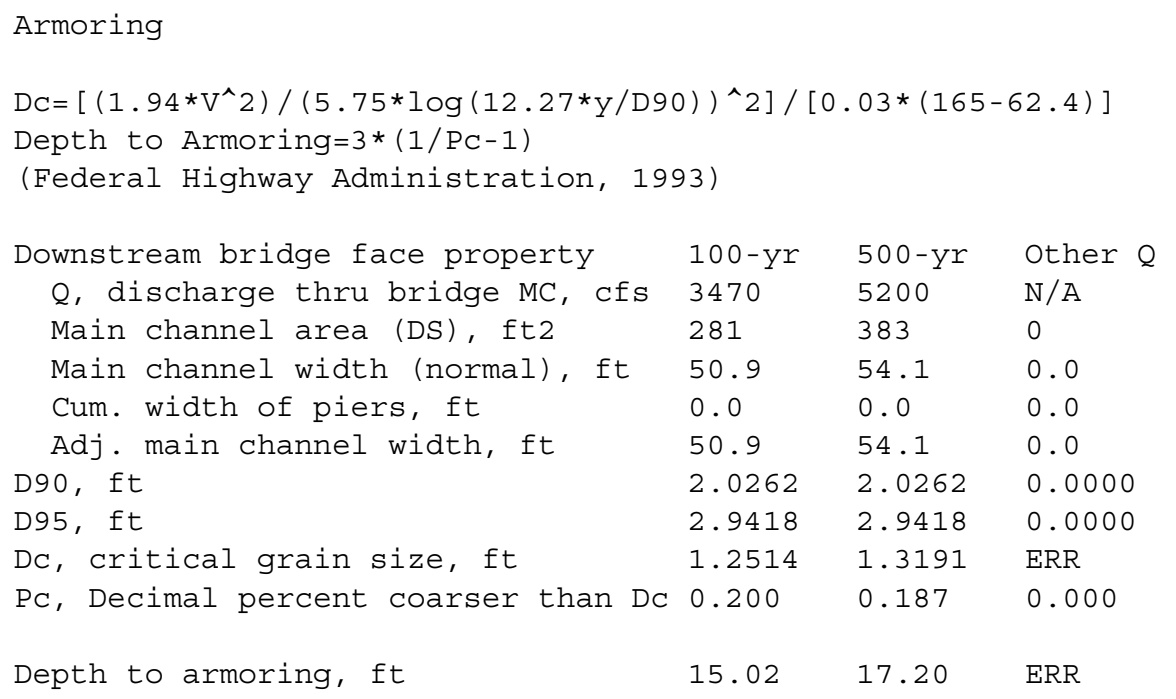




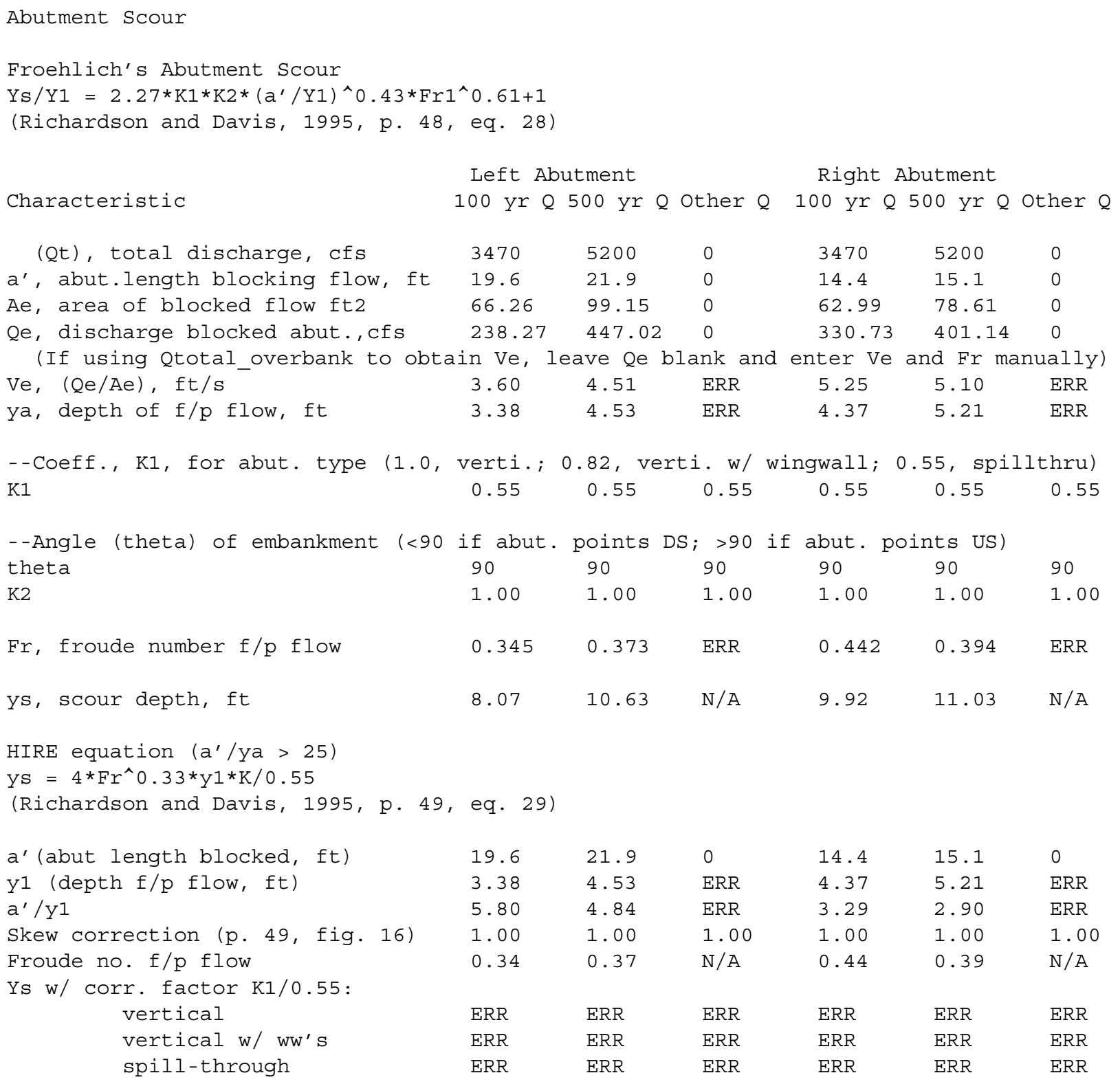




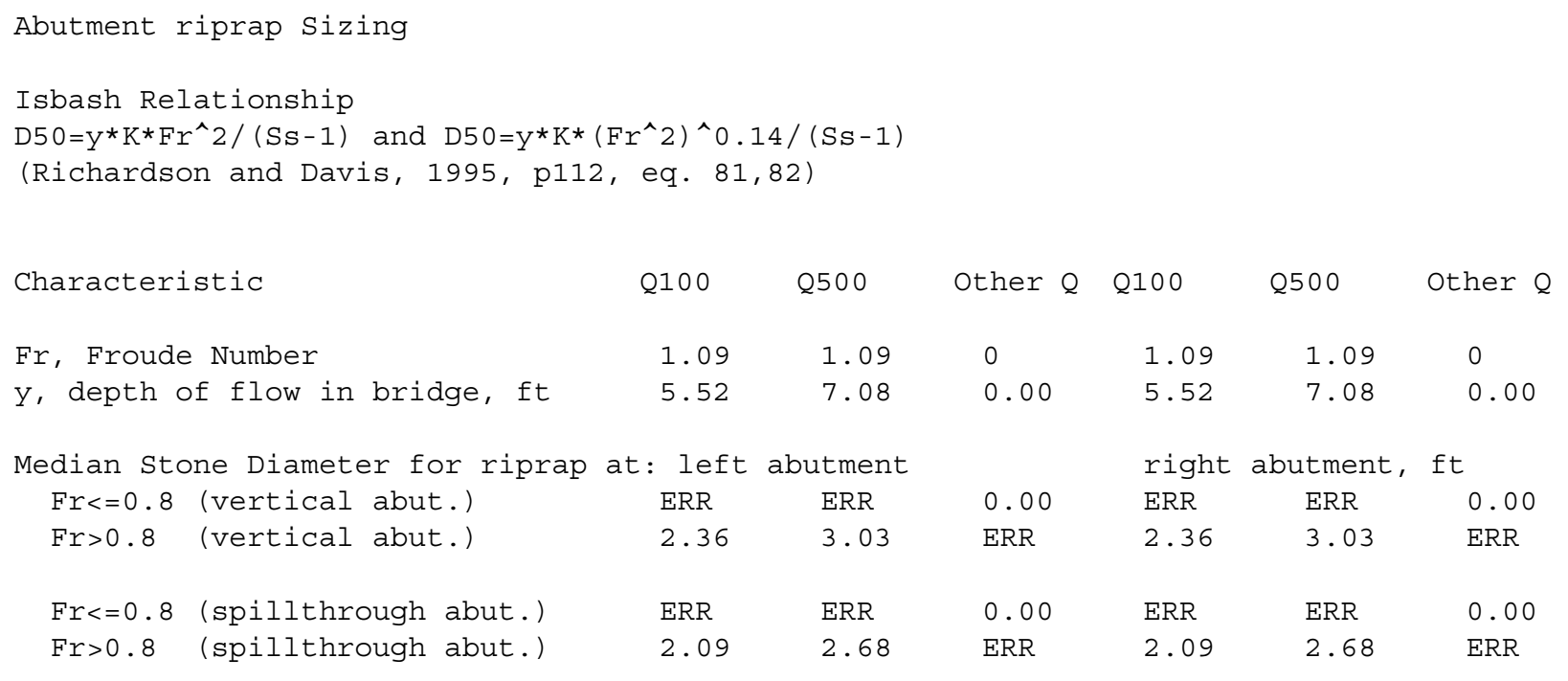

